\author{
MIKOEAJ GETKA-KENIG \\ Instytut Historii Sztuki, \\ Uniwersytet Jagielloński w Krakowie
}

\title{
RZĄDOWE PRZEDSIĘWZIĘCIA POMNIKOWE KU CZCI ALEKSANDRA I A IDEOLOGIA „WSKRZESZENIA” POLSKI W LATACH 1815-1830
}

\begin{abstract}
Abstrakt: Przedmiot analizy stanowią projekty i zarazem okoliczności budowy pomnika (pomników) ku czci cesarza rosyjskiego Aleksandra I jako „wskrzesiciela” Polski, które były związane z rządem konstytucyjnego Królestwa Polskiego (1815-1830). Jest to przyczynek do badań nad fenomenem ideologii „wskrzeszenia” Polski pod postacią Królestwa Polskiego, powstałego na mocy decyzji Kongresu Wiedeńskiego, ale z woli Aleksandra I.
\end{abstract}

Słowa kluczowe: pomniki publiczne, Królestwo Polskie, Aleksander I, naród, polityka i sztuka.
Abstract: This analysis deals with the projects and circumstances of erecting monuments in honour of Emperor Alexander I of Russia, conceived as the "resurrector" of Poland, and involving the government of the constitutional Kingdom of Poland (1815-1830). This text is a contribution to research into the ideology of "resurrecting" Poland in the form of the Kingdom of Poland established upon the basis of a decision made at the Congress of Vienna but determined by Alexander I.

Keywords: public memorials, Congress Poland, Alexander I, nation, politics and art.

Cesarz rosyjski Aleksander I (1777-1825) jest centralną postacią w dziejach konstytucyjnego Królestwa Polskiego - nie tylko jako osoba z krwi i kości, czyli jego twórca i zarazem władca, lecz również jako konstrukt ideologiczny, czyli „wskrzesiciel” (termin źródłowy) państwa polskiego, którego szeroko rozpowszechniony kult stanowił jedno z podstawowych źródeł legitymacji pokongresowego ładu. Temu ostatniemu zagadnieniu - ideologii narodowego „wskrzeszenia” z łaski Aleksandra - nie poświęcano jednak zbytniej uwagi w od dawna bujnie rozwijających się 
badaniach nad tym okresem, wprawdzie krótkim, ale dość ważnym z perspektywy całej historii ziem polskich XIX w. (chociażby ze względu na długofalowe geopolityczne skutki faktu powstania Królestwa dla ogółu ziem dawnej Rzeczypospolitej). Jak gdyby nie było sensu badać i doszukiwać się w propagandowych hasłach gloryfikujących „zaborcę" czegoś więcej niż konwencjonalnych sloganów, a więc głębszej myśli, której analiza pozwoliłaby spojrzeć na przedpowstaniowe Królestwo pod innym niż wcześniej kątem - w tym przypadku, pod kątem specyficznych wartości i idei, na których władza starała się budować autorytet „wskrzeszonego” państwa, a więc normować relacje ze społeczeństwem w dobie pozornie odzyskanej niepodległości. O ile w przypadku takich postaci jak Tadeusz Kościuszko czy ks. Józef Poniatowski nasza wiedza o ówczesnej mitologizacji ich historycznych dokonań jest znaczna, o tyle wciąż pozostaje ona dość pobieżna w odniesieniu do mitu „wskrzesiciela”, co najmniej równie ważnego dla ówczesnego pojęcia patriotyzmu i narodowej tożsamości ${ }^{1}$. Niniejszy artykuł ma więc za zadanie poszerzyć wciąż skromny stan wiedzy na temat ideologii „wskrzeszenia” poprzez skupienie się na szczegółowej analizie pojedynczego dyskursu, który się na takową składał. Tym dyskursem są bezpośrednio związane $\mathrm{z}$ rządem projekty budowy pomnika ku czci „wskrzesiciela" (z których, nota bene, udało się zrealizować tylko jeden) ${ }^{2}$.

Wybór akurat tego medium propagandy politycznej wynika z przyjmowanego przeze mnie założenia o jego szczególnym znaczeniu społecznym. Pomniki stanowią wszakże istotne narzędzie polityczno-moralnego instruowania społeczeństwa, szerząc i niejako obiektywizując w przestrzeni publicznej te wzorce postaw, które inicjator/pomysłodawca uznaje za szczególnie przyczyniające się do dobra określonej wspólnoty i tym samym zasługujące na utrwalenie w spektakularnej formie ${ }^{3}$.

1 Tematowi patriotycznego mitu „wskrzesiciela” Aleksandra poświęcono nieco uwagi w opracowaniach literaturoznawczych: E. Dąbrowicz, Galeria ojców. Autorytet publiczny w literaturze polskiej lat 1800-1861, Białystok 2009, s. 127-166; B. Burdziej, „Tytuł Pótnocy” - Aleksander I w polskiej literaturze okolicznościowej 1801-1826, „Litteraria Copernicana", t. 7, 2011, nr 1, s. 18-49.

${ }^{2}$ Niniejszy artykuł powstał na podstawie mojej rozprawy doktorskiej pt. „Pomniki w Księstwie Warszawskim, Królestwie Polskim oraz Wolnym Mieście Krakowie w latach 1807-1830: komemoracja wizualno-przestrzenna a problem zasługi we «wskrzeszonej» wspólnocie narodowej”, obronionej na Wydziale Historycznym Uniwersytetu Warszawskiego w 2016 r. (promotor: Jarosław Czubaty).

${ }^{3}$ Pomniki publiczne są obecnie popularnym przedmiotem badań poświęconych zagadnieniu wspólnotowej tożsamości, a zwłaszcza ideologii mających je kształtować; patrz np.: R. Alings, Monument und Nation. Das Bild vom Nationalstaat im Medium Denkmal - zum Verhältnis von Nation und Staat im deutschen Kaiserreich 1871-1918, Berlin 1996; P. Carrier, Holocaust Monuments and National Memory Cultures in France and Germany since 
Jak pisał w 1812 r. Sebastian Sierakowski, jeden z pierwszych polskich teoretyków sztuki pomnikowej, „są [--] pamiętniki [tj. pomniki] uroczystym hołdem, który przez wdzięczność oddaje się cnocie, dobroczynności, zasługom, końcem zachęcania żywych i potomków do czynienia dla dobra publicznego" ${ }^{4}$. Z drugiej strony, pomniki jako obiekty artystyczno-architektoniczne same w sobie stanowiły symbol cnoty wspaniałości (magnificentia), a tę w przypadku Królestwa Polskiego częstokroć wiązano ze „wskrzesicielem”. Sierakowski wprost obdarzał pomniki mianem „struktur wspaniałości publicznej”, zwracając uwagę na ich społeczną rolę w zakresie szerzenia wzniosłych moralnych ideałów. $\mathrm{W}$ jego przekonaniu, artystyczna forma pomnika miała kluczowe znaczenie dla przekazu ideowego, a co więcej, odpowiadała za jego efektywność: piękno wyrazu (dobry pomnik musiał być z zasady piękny) miało bowiem skuteczniej przekonywać o pięknie upamiętnianych czynów ${ }^{5}$.

Należy w tym miejscu zaznaczyć, że opisywane w niniejszym artykule pomniki bywały już przedmiotem analiz historycznych (ściślej, historyczno-artystycznych). Pisano jednak o nich w kategoriach narzędzia dość pobieżnie pojmowanej propagandy politycznej. Podstawowe pod tym względem prace Piotra Paszkiewicza i Tadeusza Stefana Jaroszewskiego nie wchodziły głębiej w istotę motywacji stojących za tymi przedsięwzięciami, warunkowanych ideologią narodowego „wskrzeszenia”. Co więcej, w przypadku tego pierwszego badacza stosowały wobec nich mylącą kategorię „sztuki rosyjskiej”, czyli zaborczej, co miało wpływ na interpretację ich znaczenia ${ }^{6}$. Abstrahując więc od uzupełnień o charakterze

1989, New York 2005; Contested Sites, Commemoration, Memorial and Popular Politics in Nineteenth-Century Britain, red. P.A. Pickering, A. Tyrrell, Aldershot 2004; H. Hoock, Empires of the Imagination. Politics, War, and the Arts in the British World, 1750-1850, London 2010, s. 39-202; S. Marschall, Landscape of Memory: Commemorative Monuments, Memorials and Public Statuary in Post-apartheid South Africa, Leiden 2010; S. Michalski, Public Monuments. Art in Political Bondage 1870-1997, London 1998; H.A. Pohlsander, National Monuments and Nationalism in 19th Century Germany, Bern 2008; H. Rausch, Kultfigur und Nation. Öffentliche Denkmäler in Paris, Berlin und London 1848-1914, München 2006; K. Savage, Standing Soldiers, Kneeling Slaves. Race, War, and Monument in Nineteenth-Century America, Princeton 1997; S. Webster, The Nation's First Monument and the Origins of the American Memorial Tradition, Abingdon 2015.

${ }^{4}$ S. Sierakowski, Architektura obejmujacca wszelki gatunek murowania i budowania, t. 1, Kraków 1812, s. 218.

${ }^{5}$ Ibidem, t. 1, s. 217-219.

${ }^{6}$ P. Paszkiewicz, Pod berłem Romanowów. Sztuka rosyjska w Warszawie 1815-1915, Warszawa 1991, s. 156-159, 160-161; idem, Carskie pomniki i architektura okazjonalna $w$ Warszawie (1815-1915). Treści i funkcje ideowe, „Biuletyn Historii Sztuki”, t. 52, 1990, nr 3/4, s. 287-317; T.S. Jaroszewski, Kościół św. Aleksandra, Warszawa 1973; idem, Chrystian Piotr Aigner. Architekt warszawskiego klasycyzmu, Warszawa 1970, s. 236-243. 
faktograficznym, niniejszy artykuł proponuje nową perspektywę patrzenia na ten znany już w literaturze fenomen, jakim były rządowe projekty pomnikowe ku czci Aleksandra I.

Konstytucyjne Królestwo Polskie, rozpatrywane w kategoriach wspólnoty państwowo-narodowej opartej na spajających ją ideologicznych podstawach, pod wieloma względami stanowiło kontynuację Księstwa Warszawskiego ${ }^{7}$. W obu dominowało przeświadczenie, że stanowią „wskrzeszoną", choć zarazem niepełną Polskę, będąc instytucjonalnie ugruntowanym punktem wyjścia (pierwszym etapem) do pełnej realizacji rezurekcyjnego (jest to chyba stosowny przymiotnik $\mathrm{w}$ tym kontekście) projektu. Co więcej, w obu państwach „wskrzeszenie” nie miało, w wyobrażeniu współczesnych, stanowić bezpośredniego efektu własnych działań, lecz być przejawem łaskawości zewnętrznej siły, doceniającej wysiłek narodu, który nie był w stanie dobić się państwowości bez pomocy silnego protektora. Obie wizje „wskrzeszenia” różnił jednak znacznie kontekst międzynarodowy. Lata 1807-1813 upływały w cieniu europejskiego konfliktu, dającego nadzieję na rychłą transformację kadłubowego Księstwa, tym bardziej że francuski „wskrzesiciel” pozostawał w napiętej relacji z mocarstwami rozbiorowymi. Po $1815 \mathrm{r}$. miano do czynienia $\mathrm{z}$ powszechnym oraz prognozowanym na długie lata pokojem, w najbliższym czasie nie dającym szans na poważniejsze zmiany w skali międzynarodowej. Wielu mogło się wydawać, że nie było ku temu potrzeby, gdyż w roli „wskrzesiciela” występował ten, pod którego berłem znajdowały się rozległe tereny litewsko-ruskie, stanowiące gros obszaru dawnej Rzeczypospolitej. Jak wspominał po latach raczej mało przychylny Romanowom Walerian Łukasiński: „wiele osób, nawet rozsądnych, utrzymywało, że Napoleon nie mógł nam dać ani jednej stopy ziemi bez wojny i ofiar z naszej strony, przeciwnie cesarz Aleksander może powiększyć nasze małe Królestwo całymi prowincjami bez straty dla siebie, zyska jeszcze tylko na tym, że Polaki [sic!], nosząc swoje imię, będą mu lepiej służyć aniżeli nazywając się Rosjanami”8.

${ }^{7}$ Również w pojęciu współczesnych - patrz np.: [A. Ostrowski], Żywot Tomasza Ostrowskiego, t. 2, Paryż 1840, s. 630.

${ }^{8}$ W. Łukasiński, Pamiętnik, Warszawa 1960, s. 63. Z najnowszych badań nad polityką Aleksandra I wobec Polaków w tym okresie, jak i wcześniej, patrz: A. Barańska, Polityka polska Aleksandra I, w: Wolnomularstwo Narodowe. Walerian Eukasiński, red. W. Śliwowska, Warszawa 2014, s. 37-72. 
Równocześnie, nowe „wskrzeszenie” dotyczyło nie Księstwa, lecz Królestwa i nie Warszawskiego, ale Polskiego (kwestia nazewnictwa była niebagatelna). Fakt, że kolejny raz zawdzięczano je monarsze, ugruntowywał tak bardzo charakterystyczny dla tego momentu w polskiej historii i zarazem obcy przedrozbiorowej tradycji (przynajmniej poprzednich dwóch stuleci) kult monarchy, od którego i tak wszystko pod względem politycznym zależało i który mógł jeszcze wiele dobrego dla Polaków uczynić.

Warto zauważyć, że w Księstwie najwyższe władze państwowe wcale nie paliły się do honorowania Napoleona pomnikami. Potrzebę wzniesienia takowych zgłaszali natomiast ci, którzy rywalizowali z rządem warszawskim o względy Francuzów. Takie inicjatywy podejmowali w $1808 \mathrm{r}$. generałowie Józef Zajączek (pod Kaliszem) i Jan Henryk Dąbrowski (pod Poznaniem), przez lata walczący pod rozkazami Bonapartego, i dlatego też zazdrośni o niezasłużone ich zdaniem wyniesienie J. Poniatowskiego na urząd ministra wojny ${ }^{9}$. Motywacje stojące za tym charakterystycznym postępowaniem rządu warszawskiego pozostają enigmatyczne w świetle źródeł, choć można zaryzykować tezę, że powodem była niechęć do podkreślania trwałości Księstwa (samonarzucającej się w przypadku dyskursu pomnikowego, z samej swojej natury mającego uwieczniać promowane przez siebie idee). Świadczy o tym fakt, że pierwszy pomysł upamiętnienia Napoleona (o którym będzie jeszcze mowa w tym artykule) został oficjalnie ogłoszony na najwyższym państwowym szczeblu dopiero w 1812 r., tuż po wybuchu wojny z Rosją, której sukces powszechnie uznawano wówczas za pewny. Rząd polski po 1815 r. od początku postępował pod tym względem zdecydowanie inaczej. Działając w realiach pokongresowego ładu, uchodzącego za trwały, nie promował on (nawet pośrednio) ewolucyjnej wizji „wskrzeszenia”, lecz odwoływał się do tego typu spektakularnych sposobów utwierdzania Polaków w przekonaniu o wielkości tego daru, który już otrzymali z rąk Aleksandra i na którym ich uwaga powinna się teraz skupić.

18 maja 1816 r. na łamach „Gazety Warszawskiej” opublikowano pismo ministra spraw wewnętrznych Tadeusza Mostowskiego do namiestnika J. Zajączka. Datowane na 10 maja, dotyczyło ono projektu wystawienia bramy triumfalnej „w miejscu, gdzie Wskrzesiciel Polski wstąpił” po raz pierwszy (a wówczas jak dotąd jedyny) „w krańce Warszawy” jako

${ }^{9}$ Na temat tych inicjatyw patrz: J. Polaczek, Sztuka i polityka w Księstwie Warszawskim, Rzeszów 2005, s. 134-142. 
król polski ${ }^{10}$. Według Mostowskiego miał być to pomnik „bytu naszego” i wynikającej z tego faktu „wdzięczności” Polaków wobec „najlepszego z królów”, który „wolnie” nimi „rządził”. Te ostatnie słowa zdawały się odnosić czytelnika do staropolskiej tradycji i przedrozbiorowego pojęcia „wolnego rządu”, stanowiącego fundament polsko-litewskiej tożsamości ${ }^{11}$. „Wolność” królewskich rządów mogła stanowić w tym ujęciu kluczowy dowód polskości „wskrzeszonego” państwa, sprowadzając się zresztą przede wszystkim do oparcia władzy prawodawczej na współpracy króla i dwuizbowego sejmu, który sam w sobie stanowił jeden z najważniejszych symbolicznych łączników pomiędzy dawną i nową Polską. Nawet jeżeli zarówno litera, jak i duch konstytucji 1815 r. znacznie odbiegały od staropolskiego modelu tej współpracy, dając przewagę czynnikowi monarchicznemu, Mostowskiemu musiało zależeć na podkreśleniu dobrze kojarzącej się Polakom politycznej „wolności”, której zewnętrzne znamiona były zachowane. $Z$ drugiej strony, tego typu liberalny system rządów ${ }^{12}$ osiągnął po $1815 \mathrm{r}$. status niemal paradygmatu politycznej nowoczesności doby Restauracji, stając się udziałem wielu państw w Europie ${ }^{13}$. Z nadwiślańskiej perspektywy był to co prawda fakt, jak się wydaje, o mniejszym znaczeniu, choć wciąż ważny. Wszakże przywiązaniu do rodzimej tradycji towarzyszyła duma z tego, że ustrój „wskrzeszonej” Polski może być obiektem podziwu i zazdrości tych europejskich narodów, które aż tak dalece zaawansowanego stopnia wolności nie osiągnęły ${ }^{14}$. Nawet jeżeli dopatrywalibyśmy się w takim nastawieniu tendencji do zaklinania rzeczywistości (choć w porównaniu z innymi konstytucjami tego czasu polska ustawa zasadnicza rzeczywiście wysuwała się na czoło pod względem swojej liberalności, co zresztą polska historiografia od dawna podkreśla), nie o prawdę tutaj chodziło, lecz o skuteczną

10 „Gazeta Warszawska”, 18 V 1816, nr 40 (dodatek).

11 Patrz: A. Grześkowiak-Krwawicz, Regina libertas. Wolność w polskiej myśli politycznej XVIII wieku, Gdańsk 2006.

12 Przyjęte przeze mnie rozumienie terminu „liberalny” w odniesieniu do okresu pokongresowego odpowiada definicji, którą przedstawił Brian E. Vick w monografii The Congress of Vienna. Power and Politics after Napoleon (Cambridge, Mass. 2014, s. 236): „Liberal is here used in the sense of a program of constitutional limits to monarchical authority and certain basic protections for individual and group rights in society and polity (roughly, the rule of law), coupled with some measure of representation and political participation for an at least somewhat expanded body of citizens".

${ }^{13}$ Ibidem, s. 233 n.; patrz również: M.J. Prutsch, „Monarchical Constitutionalism” in Post-Napoleonic Europe. Concept and Practice, w: Constitutionalism, Legitimacy, and Power. Nineteenth-Century Experiences, red. K.L. Grotke, M.J. Prutsch, Oxford 2014, s. 69-83.

${ }^{14}$ Mowa Józefa Wybickiego przy połączeniu Izby poselskiej z senatorską z 27 III 1818 r., w: Diariusz Sejmu Królestwa Polskiego, t. 1, Warszawa [1818], s. 9. 
perswazję, wykorzystującą przywiązanie Polaków do parlamentarnych tradycji z jednej strony i do niemniej tradycyjnego przekonania o własnej wyjątkowości z drugiej strony. Zapewnienie „wolnych rządów” we „wskrzeszonej” Polsce było więc już samo w sobie niebagatelną zasługą Aleksandra, mogącą jak najlepiej o nim świadczyć o oczach Polaków. Jednak stawała się ona o tyle znaczniejsza, o ile brało się pod uwagę kontekst, w którym Aleksander zgodził się tak bardzo uszczęśliwić nowych poddanych. Mostowski podkreślił bowiem miłosierną postawę „wskrzesiciela” wobec tych, których obdarzył dobrodziejstwami, zamiast ich karać jako niedawnych wrogów z 1812 r. Jak zaznaczał, choć „mogliśmy paść pierwszą usprawiedliwionej zemsty [podkreślenie - M.G.K.] ofiarą” i „ród nasz mógł zniknąć z ziemi naszej”, tak się jednak nie stało i natchniony przez Boga jego pomazaniec, odtrąciwszy od siebie „zapalczywe głosy” doradzających zemstę na Polakach, „wśród ogromnej swej potęgi raczył ocenić usiłowania szlachetnej, choć bezsilnej odwagi”. Wielkość Aleksandra nabierała więc mistycznego charakteru, przepojonego duchem chrześcijańskiego miłosierdzia i zarazem sprawiedliwości w stosunku do narodu, który podjął z nim walkę nie z nienawiści, lecz z czystej rozpaczy, nie pragnąc nic więcej, jak tylko odzyskania swojego państwowego bytu.

Pomysł wystawienia bramy triumfalnej sam w sobie zasługuje na uwagę. Mostowski uzasadniał go chęcią upamiętnienia pierwszego wjazdu cesarza-króla do Warszawy w 1815 r., co z kolei miało na celu podkreślać znaczenie stolicy jako miejsca, w którym doszło do nadania Polakom „wolnej” konstytucji, stanowiącej fundament i zarazem rękojmię „wskrzeszenia”. Brama nadawała jednak temu pomnikowemu dyskursowi „wdzięczności i bytu naszego" jednoznacznie triumfalistyczny wymiar. Za triumfatorów mogli uchodzić zarówno Aleksander (którego militarne sukcesy przyniosły Polakom tak szczęśliwe skutki), jak i do pewnego stopnia Polacy jako odbiorcy zasłużonej nagrody za swoje wieloletnie niepodległościowe starania. Jednak to pierwszeństwo Aleksandra było na tym polu bezsprzeczne. Brama odwoływała się wszakże wprost do praktyki wystawiania tego typu monumentów ku czci niektórych rzymskich cezarów jako zwycięskich wodzów. Zresztą, nierzadko pojawiały się w ówczesnych wypowiedziach publicznych rozmaite skojarzenia cesarza rosyjskiego z jego wybranymi rzymskimi odpowiednikami, w tym przede wszystkim ze znanym ze swojej łaskawości Tytusem (nota bene, adresatem jednej z bram zachowanych na Forum Romanum $)^{15}$.

Kontekst przestrzenny także nie był pozbawiony ideologicznego znaczenia. Pomnik miał stanąć w tym samym miejscu, w którym w chwili

15 B. Burdziej, op. cit., s. 18-49. 
wjazdu Aleksandra do Warszawy wznosiła się tymczasowa konstrukcja również mająca kształt bramy. Była to dawna praktyka, znana zarówno w Księstwie Warszawskim (zresztą dokładnie w tym samym miejscu w 1809 r. stała brama ku czci wojska polskiego pod wodzą ks. J. Poniatowskiego, od tej strony powracającego do Warszawy po zwycięstwie galicyjskim), jak i za Stanisława Augusta, nie mówiąc o czasach wcześniejszych ${ }^{16}$. Ze względu na swoją tymczasowość brama z 1815 r. nie miała jednak charakteru pomnikowego i tym samym niczego nie upamiętniała, a jedynie dodawała splendoru pojedynczej uroczystości. To, co jednak integralnie łączyło oba obiekty, to oprócz miejsca i klasycznego modelu także funkcja, jaką pełniły one w przestrzeni miasta. Jak się bowiem wydaje, brama-pomnik musiała odgrywać rolę komunikacyjną, stojąc na trasie przejazdu do centrum miasta. Tym samym stawałaby się ona integralnym elementem nowego traktu prowadzącego od Mokotowa i mijającego znajdujące się przy obecnym placu Unii Lubelskiej rogatki, i dalej wiodącego przez plac Na Rozdrożu aż do miejsca wystawienia tymczasowej bramy w 1815 r., czyli dzisiejszego placu Trzech Krzyży, a więc tam, gdzie zaczynała się zwarta zabudowa miejska. Przestrzeń zaaranżowaną wokół wzniesionych w 1816 r. rogatek mokotowskich określano w ówczesnej prasie mianem jednego z ,pierwszych w Europie do miast stołecznych wjazdów"17. Był to wczesny przejaw intensywnie rozwijanych w kolejnych latach prac mających na celu racjonalizację i "upiększanie” stolicy Królestwa (nie tylko siedziby króla i jego rządu, ale i miejsca, gdzie byt „wskrzeszonej” Polski został ostatecznie i publicznie przypieczętowany) poprzez wytyczanie nowych alei, placów, jak i wznoszenie bądź przebudowywanie budynków przeznaczonych dla instytucji „wskrzeszonego" państwa ${ }^{18}$. Brama ku czci „wskrzesiciela” stawała się w ten sposób sama w sobie elementem modernizacyjnego dyskursu, do którego odwoływały się polityczne elity sprawujące swoje rządy w imieniu „wskrzesiciela" i prezentujące cywilizacyjny rozwój jako swoją misję ${ }^{19}$.

16 Patrz: J. Polaczek, op. cit., s. 94-95, 99-102; M. Kwiatkowski, Stanisław August król-architekt, Wrocław 1983, s. 165.

17 „Gazeta Warszawska”, 19 X 1816, nr 84 (dodatek); patrz akwarela aut. Jana Thomasa z ok. 1820 r. ze zbiorów Muzeum Akademii Sztuk Pięknych w Petersburgu, reprodukowana w: M. Kwiatkowski, Nieznane widoki i plany warszawskich odwachów i rogatek celnych, „Biuletyn Historii Sztuki”, t. 21, 1959, nr 1, s. 88 (il. 4).

18 Patrz: W. Trzebiński, Aleksander I a działalność urbanistyczna rządu Królestwa Polskiego w latach 1815-1821, „Kwartalnik Architektury i Urbanistyki”, t. 34, 1989, z. 1/2, s. 35-89.

19 Wymownym symbolicznym wyrazem była pod tym względem dekoracja rzeźbiarska gmachu Komisji Rządowej Spraw Wewnętrznych i Policji, uwzględniająca alegoryczne przedstawienia policji, rolnictwa i przemysłu „połączonego z kunsztami”, 
Istotną rolę w określaniu ideologicznego wymiaru tej inwestycji miało finansowanie. Mostowski proponował rozwiązać ten problem poprzez składkę. Pomnik, zgodnie z ministerialnymi deklaracjami wychodzący naprzeciwko „myślom i żądaniom powszechnym”, stawałby się w ten sposób prawdziwie narodowym przedsięwzięciem. Tym pełnym wdzięczności narodem mieli być jednak przede wszystkim ci, którzy „w jakimkolwiek stanie, urzędzie, kondycji lub czynności z jakiegokolwiek bądź tytułu lub powodu roczną opłatę z kasy Królestwa Polskiego pobierają". To właśnie z ich pensji chciano potrącać odpowiedni podatek na ten cel. Wprawdzie równocześnie nie odbierano prywatnym darczyńcom prawa do dodania swojej cegiełki, jednak nacisk kładziono na udział w składce tych, którzy współtworzyli struktury państwowe „wskrzeszonej” Polski. Ścisłe powiązanie państwa (aparatu biurokratycznego) z ideą narodu nie powinno, co prawda, zaskakiwać w świetle przedrozbiorowej tradycji, stawiającej pomiędzy nimi znak równości, co miało istotne znaczenie dla porozbiorowych wyobrażeń na temat „wskrzeszenia”20. Jednak w przeciwieństwie do Rzeczypospolitej Królestwo opierało się na scentralizowanej administracji. Dokonując w ten sposób subtelnego podziału na dwie grupy Polaków, wyraźnie dowartościowywano urzędników i oficjalistów rządowych jako najbardziej przywiązanych do osoby „wskrzesiciela”, dlatego też szczególnie predestynowanych do wyrazów wdzięczności. Planowana warszawska brama triumfalna jawi się więc jako wyraz partykularnych interesów rządu, a przede wszystkim jego dążeń do umacniania własnego autorytetu poprzez podkreślenie swojego szczególnego miejsca, które zajmował on w dziele „wskrzeszenia”, a którego beneficjentami byli wszyscy ci, którzy utożsamiali się z polskością. Cel propagandowy nie kłócił się przy tym z praktycznym wymiarem tego rozwiązania, które mogło wydawać się najbardziej skuteczną formą finansowania tego typu przedsięwzięć. Opieranie się na niezobowiązujących deklaracjach, stało się wszakże przyczyną upadku idei budowy pomnika Napoleona pod Kaliszem, której w okresie Księstwa patronował Zajączek, przez kilka lat bezskutecznie starający się wyegzekwować przyrzeczone sumy od swoich podkomendnych ${ }^{21}$. W tym przypadku rząd dysponował odpowiednimi instrumentami przymusu w stosunku

z centralnie umieszczonymi na postumencie tablicami konstytucji (niczym tablice dekalogu): cyt. za: „Kurier Warszawski”, 4 XI 1823, nr 263. Analogiczne udekorowano gmach Komisji Rządowej Przychodu i Skarbu, gdzie tarczom z orłem Królestwa przydano po bokach rogi obfitości. W obu przypadkach rzeźby zachowały się do dziś.

${ }^{20}$ T. Łepkowski, Naród bez państwa, w: Polska. Losy państwa i narodu, red. H. Samsonowicz i in., Warszawa 1992, s. 277.

${ }^{21}$ J. Polaczek, op. cit., s. 137-138. 
do swoich podwładnych, których pozostający poza aparatem władzy dowódca wojskowy nie miał.

Projekt dekretu stał się prawem z woli namiestnika 15 maja $1816 \mathrm{r}^{22}$ Planując budowę, być może miano na uwadze zbliżającą się wizytę Aleksandra pod koniec września tego roku, z której okazji wznoszono również rogatki mokotowskie. Co prawda, trudno uwierzyć, aby przewidywano ją ukończyć w tak krótkim czasie, biorąc zwłaszcza pod uwagę wszystkie dekoracje, które powinny były ją ozdabiać. Zapewne chciano chociażby zacząć, aby móc pokazać władcy postępujące prace. Plan spalił jednak na panewce ze względu na sprzeciw samego upamiętnianego, dla którego kłopotliwa okazała się dwuznaczna symbolika tej formy komemoracji. 27 lipca 1816 r. Rada Administracyjna z namiestnikiem na czele została poinformowana, że przy całym „tkliwym przejęciu [--] uczuciem wdzięczności i miłości wiernych swoich poddanych", w przekonaniu króla „rodzaj ten pomnika nie stosuje się do zamiarów, które w całym ciągu życia powodowały” jego „krokami”. Aleksander nie chciał być kojarzony z „rządzą triumfów i podbojów”, pragnąc, aby w kontekście pierwszego wjazdu do „nowych państw swoich” pamiętano go jako „ojca”, a nie „zwycięzcę"23. Jak widać, obie strony inaczej pojmowały kwestię triumfu w odniesieniu do Królestwa i relacji pomiędzy Aleksandrem a polskim społeczeństwem. Stronie polskiej negatywne skojarzenia najwyraźniej nie przychodziły na myśl w tym kontekście, i to nie tylko elicie rządowej, ale i nawet Kościuszce, który pomimo rozczarowania skalą daru Aleksandra zdecydował się finansowo wesprzeć ideę triumfalnego pomnika ku jego czci (jak sam deklarował, żywił szczerą „,wdzięczność” wobec cesarza rosyjskiego „za wznowienie imienia polskiego”), co zostało zresztą skrzętnie wykorzystane przez rząd w celach propagandowych ${ }^{24}$. Daleko posunięta ostrożność ze strony cesarza, który wolał nie akceptować decyzji swoich ministrów, zdaje się świadczyć o jego osobistych obawach co do polskich nastrojów. Trudno aby nie zdawał on sobie sprawy, że fakt ustanowienia Królestwa na drodze podboju innego państwa, również cieszącego się mianem „wskrzeszonej” Polski, mógł rodzić

22 „Gazeta Warszawska”, 18 V 1816, nr 40 (dodatek).

${ }^{23}$ Protokół Rady Administracyjnej, 27 VII 1816, AGAD, Protokoły Rady Administracyjnej Królestwa Polskiego (dalej: RAKP), sygn. 3, s. 58-59.

${ }^{24}$ „Gazeta Warszawska”, 23 VII 1816, nr 59 (dodatek pierwszy). Informację na ten temat podawał sam minister Mostowski, opatrując ją następującym komentarzem: „czyste życzenia tego męża dla prawdziwego dobra współziomków, szczupłość dochodów i niezmienny jego sposób myślenia dowodzą wspólnie w tej ofierze, z jakim zaufaniem wróży pomyślność teraźniejszym losom swej ojczyzny, i będą niezatartym hołdem całej jego wdzięczności i nadziei”. 
napięcia we wzajemnych stosunkach, których należało unikać dla dobra nowego reżimu ${ }^{25}$. $\mathrm{Z}$ drugiej strony, brak akceptacji dla tego typu dowodów wdzięczności stawiał Aleksandra w jeszcze lepszym świetle, mogąc dodatkowo umacniać przekonanie o jego cnotach i szczerej chęci działania na rzecz dobra Polaków. Chociaż trudno byłoby znaleźć jakiekolwiek uzasadnienie dla ewentualnych podejrzeń o ministerialną intrygę w tej sprawie (specjalne obmyślenie takiej formy upamiętnienia, której on nie mógłby i tak przyjąć), posunięcie Aleksandra wydaje się zręczne z propagandowego punktu widzenia. Znamienne, że zebrane dotąd pieniądze, cesarz-król polecił przeznaczyć „na dzieło wsparcia cierpiącej ludzkości". Chciał więc, aby to dyskurs dobroczynności, a nie triumfu, stanowił kontekst narodowego „wskrzeszenia” roku $1815^{26}$.

\section{III}

Idei budowy pomnika „wskrzesiciela" nie zarzucano jednak w kolejnych latach. Tym razem miał to być obiekt łączący w sobie pomnikową wspaniałość i publiczną użyteczność, a zarazem wyrażający niebiańską genezę zasług „wskrzesiciela”, jak i nie mniej jego osobistą skromność (hołd oddawano w ten sposób przede wszystkim samemu Bogu). Mowa o kościele pw. św. Aleksandra, który zdecydowano się wystawić w tym samym miejscu co bramę. Symbolika pierwszego wjazdu, a także kontekst modernizacyjny - wynikające z samej lokalizacji - uzyskiwały tutaj dodatkowy, praktyczny wymiar. Kościół miał bowiem służyć parafii ujazdowskiej, która od dawna czekała na nową świątynię, odpowiadającą prestiżowi tego konkretnego rejonu stolicy, gdzie jeszcze do niedawna

${ }^{25}$ Już podczas swojego pobytu w Warszawie w 1815 r., Aleksander, „acz przyjmowany uroczyście, dziwował się [--], jak wtedy o tym mówiono, iż większego jeszcze nie wzbudził entuzjazmu; tak wiele dla dobra Polski uczyniwszy!”. To doświadczenie mogło w nim wzbudzić wspomniane obawy. Cyt. za: [A. Ostrowski], Żywot Tomasza Ostrowskiego, t. 2, s. 604.

${ }^{26}$ Warto w tym miejscu wspomnieć, że już w październiku 1815 r. Rząd Tymczasowy Królestwa Polskiego zamierzał zaprowadzić „ofiarę wdzięczności”, a więc specjalną składkę zbieraną wśród właścicieli dóbr ziemskich celem corocznego zakupu „najmniej po włóce jednej chełmińskiej gruntu dla dwóch włościan” z danego województwa. Było bowiem „życzeniem [--] znakomitszych obywateli i ministeriów, aby jakim dobroczynnym darem uwiecznione zostały w naszym narodzie te uczucia wdzięczności, jakimi przejęci Polacy w stolicy przyjmować będę swego dobroczyńcę, swego wskrzesiciela, swego pierwszego króla". Pismo ministra spraw wewnętrznych do departamentów z 3 X 1815, AGAD, Komisja Rządowa Spraw Wewnętrznych (dalej: KRSW), sygn. 6187, s. 1-6v. Patrz również: Obraz Królestwa Polskiego w okresie konstytucyjnym, t. 1, red. J. Leskiewiczowa, F. Ramotowska, Warszawa 1984, s. 52-53. 
znajdowała się rezydencja króla Stanisława Augusta (nieprzypadkowo to właśnie na terenie Ujazdowa miano wznieść Świątynię Opatrzności ku czci Konstytucji 3 Maja) ${ }^{27}$, a od 1817 r. również samego Aleksandra (jako kolejnego właściciela Łazienek) i jego brata Konstantego (mieszkającego $\mathrm{w}$ pobliskim Belwederze ${ }^{28}$. Co ciekawe, pomysł budowy świątyni miał ponoć podać sam cesarz. Miał to jednak uczynić nie na zasadzie polecenia, lecz sugestii, wyrażonej w nieznanym obecnie liście do prezesa Senatu $^{29}$, jednego z najwyższych dostojników Królestwa (który w 1815 r. niejako w imieniu narodu przyjmował egzemplarz konstytucji z rąk ministra reprezentującego monarchę) ${ }^{30}$. Konsultacje z władcą i tak były w tym przypadku raczej konieczne, aby władze Królestwa uniknęły dalszych nieporozumień co do kreacji jego oficjalnego wizerunku nad Wisłą.

Budowa pomnika o funkcji kościoła mogła świadczyć o trosce, z jaką Aleksander odnosił się do moralnej kondycji swoich poddanych. Chrześcijańska formacja w tym kontekście wiązała się z postawą poddanego i obywatela, którą rząd chciał promować wśród mieszkańców „wskrzeszonej” Polski. Jednak równocześnie, mamy tutaj do czynienia z pośrednią sakralizacją osoby „wskrzesiciela”. Nowy kościół dedykowano rzecz jasna nie Aleksandrowi, lecz świętemu patronowi, choć zarazem w niczym nie ujmowano w ten sposób pomnikowemu charakterowi tego przedsięwzięcia. Kult św. Aleksandra ${ }^{31}$ (w nieco analogiczny sposób do kultu św. Napoleona we Francji ${ }^{32}$, a zarazem przeciwny do kultu

${ }^{27}$ Projekty kościoła ujazdowskiego stanowiły zresztą wyraźne źródło inspiracji dla architektonicznej koncepcji Świątyni Opatrzności. Patrz: M. Kwiatkowski, Stanisław August, s. 223-231.

${ }^{28}$ Idem, Belweder, Warszawa 1976, s. 38.

29 „Magazyn Powszechny”, 29 XI 1834, nr 43, s. 337. Brak pewności co do tego, kto właściwie był adresatem owego listu Aleksandra (o ile ta informacja jest prawdziwa, a nie np. przeinaczona). Należy bowiem pamiętać, że w momencie podejmowania decyzji o budowie kościoła stanowisko prezesa Senatu nie było obsadzone od przeszło roku, po śmierci Tomasza Ostrowskiego. Jego następcę wyznaczono dopiero kilka miesięcy później, a został nim Stanisław Kostka Potocki, który jednak - z racji starszeństwa pełnił obowiązki prezesa na czas wakatu (L. Dembowski, „Pamiętniki”, BC, sygn. 3811, s. 312). Nie można równocześnie wykluczyć, że Aleksander napisał go dużo wcześniej do Ostrowskiego, a faza realizacji nastąpiła po prostu w późniejszym okresie.

${ }^{30}$ K. Bartoszewicz, Utworzenie Królestwa Kongresowego, Kraków 1916, s. 236.

31 Ten kult przeniósł się również poza Warszawę, np. do Suwałk (znajdujących się blisko granicy rosyjskiej i drogi na Petersburg), gdzie również stanął kościół dedykowany temu patronowi: T.S. Jaroszewski, Chrystian Piotr Aigner, s. 279.

${ }^{32}$ Postać tego świętego była w zasadzie wymysłem napoleońskiej propagandy. Patrz: V. Petit, Religion du souverain, souverain de la religion: l'invention de saint Napoléon, „Revue Historique”, t. 314, 2012, nr 3, s. 643-658; S. Hazareesingh, The Saint-Napoleon. Celebration of Sovereignty in Nineteenth-Century France, Cambridge 2004, s. 3-4. 
św. Stanisława uprawianego przez Stanisława Augusta, który wykorzystywał autorytet tej popularnej historycznej postaci w celu umocnienia swojej pozycji w społeczeństwie ${ }^{33}$ ) był w zasadzie specyficzną formą kultu „wskrzesiciela”. Św. Aleksander pozostawał w tym kontekście postacią anonimową, której nie identyfikowano w oficjalnych wypowiedziach i dokumentach, choć postaci o tym imieniu, które czczono w Kościele katolickim, było już wówczas kilka. Jedyną wskazówkę pod tym względem stanowiła data odpustu parafialnego, który obchodzono 12 grudnia $^{34}$, a więc we wspomnienie św. Aleksandra i jego towarzysza św. Epimacha, męczenników z III w. (w zasadzie, to Aleksander był towarzyszem Epimacha, który odgrywa zdecydowanie donioślejszą rolę w podaniu o ich wspólnym męczeństwie) ${ }^{35}$. Jak się jednak wydaje, o wyborze akurat tego dnia na najważniejsze święto parafialne (spośród wielu innych, w których czczono świętych Aleksandrów) przesądziła jego historyczna koneksja - wszakże właśnie wtedy przypadała rocznica koronacji Aleksandra Jagiellończyka, jedynego przedrozbiorowego polskiego monarchy o tym imieniu ${ }^{36}$. Dodajmy przy tym, że właściwym patronem „wskrzesiciela” był św. Aleksander Newski, uznawany jedynie przez prawosławnych ${ }^{37}$.

26 maja 1818 r. Rada Administracyjna wydała pozwolenie na wykorzystanie dotychczas zgromadzonych środków na bramę w celu budowy kościoła ${ }^{38}$. Niecałe trzy tygodnie później, 15 czerwca, odbyła się uroczystość wmurowania kamienia węgielnego. Ówczesna prasa kładła nacisk na fakt, że to sakralne przedsięwzięcie zmierzało do zastąpienia „,bramy triumfalnej, której N. Pan nie przyjął", aby w ten sposób godnie upamiętnić „pierwsze przybycie do Warszawy Najjaśniejszego Cesarza i Króla naszego" ${ }^{39}$. Inauguracyjnego aktu miał początkowo dokonać sam namiestnik Zajączek, jednak z powodu choroby w jego zastępstwie wystąpił

33 Patrz: K.J. Czyżewski, M. Walczak, Kult świętego Stanisława w wieku XVIII w perspektywie sztuki, w: Praeminado incitat. Order świętego Stanisława 1765-1831, red. M. Zawadzki, D. Nowacki, Warszawa 2015, s. 14-17; M. Deszczyńska, „Historia sacra” i dzieje narodowe. Refleksja historyczna z lat 1795-1830 nad rola religii i Kościoła w przeszłości Polski, Warszawa 2003, s. 93.

34 „Magazyn Powszechny”, 29 XI 1834, nr 43, s. 338.

35 W. Galant, Skarbiec świętych pańskich. Żywoty świętych na wszystkie dni w roku, Monachium 1926, s. 692-693.

${ }^{36}$ J.S. Bandtkie, Krótkie wyobrażenie dziejów Królestwa Polskiego, t. 2, Wrocław 1810, s. 91.

37 Aleksander obchodził imieniny w dzień święta św. Aleksandra Newskiego, czyli 30 sierpnia (w Rosji), a 11 września w Królestwie. Jak pisano w 1818 r., był to „dzień [- - ] najdroższy dla Narodu Polskiego”, „Gazeta Warszawska”, 19 IX 1818, nr 75.

38 Protokół Rady Administracyjnej, 26 V 1818, AGAD, RAKP, sygn. 6, s. 201.

39 „Gazeta Warszawska”, 20 VI 1818, nr 49. 
minister skarbu Jan Węgleński (co nie było przypadkiem, gdyż trzymał on pieczę nad przychodami kasy państwowej i wydatkami publicznymi). Namiestnika reprezentował ponadto jego najbliższy współpracownik, radca sekretarz stanu Franciszek Ksawery Kossecki. Co znamienne, czerwcowa uroczystość miała nie tyle charakter ogólnonarodowy, ile wyraźnie rządowy. Nie uczestniczyli w niej bowiem reprezentanci innych naczelnych, a formalnie niezależnych od władzy wykonawczej instytucji, takich jak Senat czy sądy. Administracja rządowa konsekwentnie starała się więc niejako zawłaszczać kult Aleksandra. Jak się zresztą wydaje (choć nie zachowały się dokumenty dotyczące tej kwestii), oryginalny system pozyskiwania środków na ten cel został utrzymany. Nacisk na rządowy charakter tej inicjatywy prezentowała fundacyjna inskrypcja na puszce złożonej w kamieniu węgielnym, która uwzględniała jedynie namiestnika wraz z członkami Rady Administracyjnej.

W fundamentach kościoła znalazły się również medale wybite ku czci niedawno zmarłego Onufrego Kopczyńskiego i wciąż żyjącego Samuela Bogumiła Lindego. Wybór akurat tych dwóch postaci należy uznać za znamienny. Kopczyński był autorem pierwszego opracowania gramatyki polskiej, natomiast Linde zredagował pierwszy słownik. Ich zasługi dotyczyły więc języka, w którym współcześni upatrywali filar narodowej tożsamości ${ }^{40}$. Zauważmy, że publikacje ich dzieł przypadły już na okres polskiego panowania Aleksandra - fakt, do którego odnosiła się prasowa adnotacja, głosząca, że złożone w fundamentach medale mają „w najpóźniejszych latach świadczyć, jak łaskawie nam panujący Monarcha przy tylu dowodach dobroczynności w szczególnej miał zawsze opiece nauki"41. Co prawda, po 1815 r. doszło po prostu do finalizacji wieloletniego procesu badawczo-redakcyjnego w wykonaniu obu językoznawców (który w przypadku Kopczyńskiego sięgał głębokiej epoki stanisławowskiej), w optyce propagandy państwowej ich osiągnięcia prezentowano jednak otwarcie jako plony rządów „wskrzesiciela”, umacniając w ten sposób pozytywny wizerunek Aleksandra jako protektora polskości. Wszakże jeszcze w październiku 1815 r. rząd głosił, że Aleksander jako „dobroczyńca” i „wskrzesiciel” był tym, który nie tylko „nadał znowu” Polakom „byt w rzędzie Narodów Europejskich, ale i „powrócił” im „imię i język ojczysty" (chodzi o używanie języka polskiego jako urzędowego, dotyczyło to jednak również Księstwa Warszawskiego), co znaczeniowo wiązało się z dalej wymienioną zasługą „zawarowania tej tak wszystkim ludom drogiej i miłej nam właściwej narodowości w prawach, w rządzie,

\footnotetext{
${ }^{40}$ A.F. Grabski, Myśl historyczna polskiego oświecenia, Warszawa 1976, s. 390.

41 „Gazeta Warszawska”, 20 VI 1818, nr 49.
} 
w religii, w wychowaniu, w oświeceniu publicznym, w sądownictwach i w narodowym rycerstwie" 42 .

Wspomnianemu doniesieniu prasowemu towarzyszył szczegółowy opis projektu architektonicznego, który powstał najpewniej (jak stwierdził T.S. Jaroszewski) we współpracy z samym projektantem, czyli budowniczym generalnym rządowym Chrystianem Piotrem Aignerem (który w tym samym czasie prowadził przebudowę warszawskiego pałacu Radziwiłłów na siedzibę namiestnika i Rady Administracyjnej) ${ }^{43}$. Szczegółowość tego tekstu wydaje się wskazywać na wielką wagę przykładaną do architektonicznej formy, która miała świadczyć o wspaniałości Aleksandra, jak i zarazem o skali polskiej wdzięczności. Świątyni, nazywanej zresztą wprost „pomnikiem” w tym opisie, miano nadać kształt rotundy wzorowanej na rzymskim Panteonie, jednym ze współczesnych architektonicznych ideałów, do którego odwoływano się przy okazji szczególnie prestiżowych fundacji sakralnych. Aigner już raz miał okazję korzystać z tego wzorca przy projektowaniu kościoła Wniebowzięcia Najświętszej Marii Panny w Puławach, którego monumentalna architektura, korzystnie wyeksponowana poprzez spektakularne umiejscowienie na szczycie lekko opadającej skarpy na obrzeżach przypałacowego parku, służyła sławie rodu Czartoryskich. Kościół przeznaczono bowiem na kaplicę grobową, dedykowaną pamięci zmarłej „ukochanej” matki księcia Adama Kazimierza, Marii Zofii z Sieniawskich ${ }^{44}$ - stąd jego maryjne i zarazem rezurekcyjne wezwanie. Prasa bezpośrednio kojarzyła zresztą warszawską budowlę z Puławami, ale nie ze wspomnianym kościołem, lecz ze Świątynią Sybilli, określaną mianem „pomnika narodowego poświęconego rycerzom polskim". Pretekstu do podkreślenia tej łączności dostarczał projektowany prześwit w kopule przykryty szybą z jednej tafli („,sztuki”) szkła o obwodzie 24 stóp (czyli przeszło 7 metrów), mający być „podobnym do tego” z Puław. To dość oryginalne skojarzenie mogło oczywiście świadczyć o autentycznej sławie puławskiej szyby (kilkumetrowe płaszczyzny szkła stanowiły w owym czasie wielką rzadkość na terenie Królestwa - i nie tylko - ze względu na kosztowność procesu tworzenia) ${ }^{45}$, której wspomnienie pozwalało wyobrazić

42 Pismo ministra spraw wewnętrznych do departamentów, 3 X 1815, AGAD, KRSW, sygn. 6187, s. 1.

${ }^{43}$ T.S. Jaroszewski, Kościót św. Aleksandra, s. 15

${ }^{44}$ Idem, Chrystian Piotr Aigner, s. 128.

45 Dar Aleksandra I dla biblioteki publicznej przy Uniwersytecie Warszawskim w postaci dwóch dużych „tafli szklanych” był wielkim wyróżnieniem dla tej instytucji, godnym podkreślenia we współczesnym przewodniku po mieście. Ł. Gołębiowski, Opisanie historyczno-statystyczne miasta Warszawy, Warszawa 1827, s. 152. 
sobie, jak wspaniałe wyposażenie będzie miała warszawska świątynia, nawet $\mathrm{w}$ takim szczególe symbolicznie poświadczając polskie wyobrażenie o wielkości Aleksandra. Jednak z drugiej strony, przywołanie tego powszechnie znanego puławskiego pawilonu mogło mieć na celu subtelne zaznaczenie ideowego powinowactwa pomiędzy jednym i drugim pomnikiem narodowym. Wcześniejszy stanowił wszakże miejsce kultu chwalebnej przeszłości, w imię wiary w szczęśliwe przeznaczenie tak bardzo przecież znakomitego (i nie mogącego być tak po prostu zmiecionym z powierzchni ziemi) narodu ${ }^{46}$. Późniejszy symbolizował natomiast ziszczenie się tych marzeń poprzez natchnioną boską wolą działalność Aleksandra, mającego być właśnie tym narodowym mesjaszem, którego nadejście puławska Sybilla zdawała się poprzednio głosić. Izabela Czartoryska dowiodła zresztą kilka lat później, że sama identyfikowała się z tym przekonaniem, kiedy z okazji uroczystości żałobnych ku czci Aleksandra, które w 1826 r. odbywały się w Puławach i Końskowoli, „bliskość Sybilli, tego zbioru dawnych polskich pamiątek, dostarczała dla wymienionych kościołów nader rzadkich i kosztownych ozdób”. Księżna przekazała wówczas „po różnych dawnych królach polskich pamiątki” do ozdoby symbolicznych katafalków ku czci zmarłego, pragnąc wywołać wrażenie, „jak gdyby monarchowie, którzy się nam tym sposobem raz jeszcze na świecie ukazali, chcieli należeć do hołdów oddawanych obrońcy ich starożytnego Tronu, Wskrzesicielowi Królestwa Polskiego"47. Zasługa Aleksandra wobec Polaków mogła się wydawać tak historycznie doniosła, że aby w pełni oddać jej znaczenie, wypadało nawet przemawiać w imieniu zmarłych. Nic nie mogło bowiem lepiej oddziałać na wyobrażenie o wielkości dokonań cesarza-króla na rzecz polskiego narodu niż hołd ze strony równych mu godnością poprzedników. Nie powinno więc dziwić, że informacja na temat tej prywatnej uroczystości została uwzględniona w pamiątkowej publikacji dotyczącej oficjalnych obchodów żałobnych w Warszawie. Czartoryska w pełni afirmowała bowiem rządowy kult „wskrzesiciela”.

Projekt Aignera prezentował się okazale. Co prawda dużo mniejszy od rzymskiego odpowiednika, warszawski Panteon miał się odznaczać nie jedną, ale dwiema „głównymi facjatami”, z wolnostojącymi korynckimi portykami, z których „pierwsza i celniejsza” miała zwracać się w kierunku Alei Ujazdowskich, a więc do przybywających od strony owego

${ }^{46}$ Wyrazem tej idei był np. poemat Jana Pawła Woronicza pt. Światynia Sybilli $\mathrm{z} 1801 \mathrm{r}$.

47 Opis żałobnego obchodu po wiekopomnej pamięci Najjaśniejszym Aleksandrze I, Cesarzu Wszech Rosji, Królu Polskim w Warszawie w dniach 7, 9, 10, 11, 12, 13, 17, 19, 23 kwietnia 1826 roku uroczyście odbytego, Warszawa 1829, s. 16. 
godnego europejskich stolic wjazdu mokotowskiego. Ponadto było to również zapewne podyktowane przeznaczeniem świątyni do użytku parafii ujazdowskiej: frontem kierowała się bowiem w stronę tej dzielnicy. Drugi portyk miał stanowić przedmiot podziwu od strony Nowego Światu. Wnętrze, również w wielu aspektach powielające rzymski przykład, miało być artykułowane kolumnami i pilastrami korynckimi, wyrażając w ten sposób typowo klasycystyczne przekonanie o architektonicznej wspaniałości (ten porządek uchodził za najbardziej wyrafinowany i stosowano go w szczególnych przypadkach ${ }^{48}$. Strukturalnej całości dopełniała potężna kopuła. Jak wyraźnie podkreślono, kościół nie miał wcale „zalecać się” swoją skalą, raczej dość skromną i wynikającą ze „szczupłości parafii”, dla której go przeznaczano, jak również z dość ograniczonej przestrzeni pozostawionej do dyspozycji architekta (i tak dokonano kilku wyburzeń w związku z planowaną budową) ${ }^{49}$, nie pozwalającej na postawienie większej budowli. Dochodziła tutaj jeszcze kwestia środków finansowych na to przedsięwzięcie, szczególnie kosztowne przede wszystkim z tego powodu, że realizowane od podstaw, a nie jak w przypadku wielu innych gmachów publicznych, na bazie starszych struktur. O jakości tej pomnikowej architektury świadczyć miały jej „kształt, wytworność i zbliżenie do" idealizowanego „gustu starożytności” czy (jak pisano rok później) proporcje, „będące duszą prawdziwej architektury" ${ }^{50}$. Tworząc budynek w założeniu idealny, planowano w ten sposób oddać szczególną wagę przedmiotu upamiętnienia.

Istotnym elementem projektowanej dekoracji wnętrza miały być „rzeźby i popiersia na uwiecznienie sławnych w narodzie mężów”, ustawione w niszach wokoło nawy. Nie wiadomo, co prawda, czy mieli to być bohaterowie dawnych wieków, czy systematycznie dokooptowywani zasłużeni czasów współczesnych, a więc ci, którzy aktywnie angażowali się w rozwój „wskrzeszonej” ojczyzny. Powiązanie kultu „wskrzesiciela” z komemoracją wybitnych Polaków stanowi jednak znamienny zabieg sam $\mathrm{w}$ sobie. Był to niejako pomnik w pomniku, a jego ewidentnym celem była promocja firmowanego przez władzę królewską modelu

${ }^{48}$ Jak pisał Sierakowski: ,jakażkolwiek bądź, to pewna, że nic piękniejszego, nic delikatniejszego, nic bogatszego, mimo sławnych geniuszów, które po Kalimachu aż do naszych czasów nastąpiły, mimo zachęcania ich, i wyznaczenia nagród od monarchy francuskiego Ludwika XIV, dowcip ludzki w architekturze, nad kapitel kolumny korynckiej nie wynalazł. Porządku tego Grecy używali tylko do tych budowli, które równie wspaniałymi, jak bogactwami i ozdobami obsypane mieć chcieli”, S. Sierakowski, op. cit., t. 1, s. 43.

${ }^{49}$ T.S. Jaroszewski, Kościół św. Aleksandra, s. 9.

50 „Gazeta Warszawska”, 5 X 1819, nr 80. 
obywatelskiej zasługi (do przyjęcia takiego założenia może nas skłaniać chociażby wcześniejsza praktyka dotycząca publicznych galerii znakomitości), na którym miała opierać się polityczna moralność „,wskrzeszonej” Polski. Analogii można doszukiwać się chociażby w Sali Rycerskiej na Zamku warszawskim. Honorując sławne postaci z narodowej przeszłości, dokonywała ona ich selekcji pod kątem zaangażowania we współpracę, a nie $\mathrm{w}$ walkę $\mathrm{z}$ monarchą i służyła tym samym propagandzie niezbyt popularnego króla-reformatora Stanisława Augusta. Zresztą, władcy zarówno Aleksander, jak i Stanisław August oraz inni w Europie przełomu wieków - mieli rozmaite narzędzia wykorzystywania dyskursu zasługi publicznej w swojej propagandzie, z instytucją orderów zasługi na czele, które w odróżnieniu od postfeudalnych orderów rycerskich stanowiły produkt nowoczesnego państwa biurokratycznego. Różnica polegała jednak na tym, że rozdawnictwo orderów dotyczyło szerokich kręgów elity państwowej, natomiast tego typu przedsięwzięcia pomnikowe miały za zadanie tworzyć wysoce ekskluzywny i ponadczasowy kanon osobowych wzorców - swego rodzaju panteon współtwórców wielkości i wspaniałości danego państwa, co akurat w omawianym tutaj przypadku nie było zapewne bez związku z formą, jaką kościół św. Aleksandra się odznaczał ${ }^{51}$.

Prace trwały aż do wiosny 1825 r., kiedy prasa powiadamiała, że „pomnik wdzięczności [- - ] już zewnątrz i wewnątrz ukończony został”, a klucz do kościoła przekazany przez Aignera namiestnikowi, znalazł się następnie w rękach proboszcza ${ }^{52}$. Tak znaczny czas budowy, której zakończenie z początku optymistycznie przewidywano na rok $1820^{53}$, wynikał zapewne $z$ niedoboru odpowiednich środków finansowych (a przyczyną takowego mógł być zły kosztorys), który zadecydował o rezygnacji z wielu dekoracyjnych i zarazem kluczowych dla ideologicznego przekazu elementów, ograniczając efekt pomnikowej wspaniałości przede wszystkim do elementów stricte architektonicznych. Jak zauważał bowiem T.S. Jaroszewski, to, co ostatecznie zostało oddane do użytku, stanowiło skrajny (o ile nie najskrajniejszy) przykład „oszczędności detalu i umiaru", które charakteryzowały dorobek Aignera ${ }^{54}$.

${ }^{51}$ W okresie napoleońskim Panteon w Rzymie został zresztą przekształcony w świątynię narodowej zasługi na polu działalności kulturalnej: wybrani artyści pióra, pędzla czy dłuta zostali w jego wnętrzu upamiętnieni pod postacią popiersi: S. Pasquali, From the Pantheon of Artists to the Pantheon of Illustrious Men. Raphael's Tomb and its Legacy, w: Pantheons: Transformations of a Monumental Idea, red. R. Wrigley, M. Craske, Aldershot 2004, s. 48.

52 „Kurier Warszawski”, 1 VII 1825, nr 154.

53 "Gazeta Warszawska”, 5 X 1819, nr 80.

54 T.S. Jaroszewski, Kościót św. Aleksandra, s. 22. 
Oprócz podobizn „sławnych w narodzie mężów” kościół został pozbawiony dekoracji malarskiej we wnętrzu. Początkowo jej wykonanie zlecono florenckiemu artyście Niccoli Montiemu. Ten niedoszły profesor malarstwa na Uniwersytecie Warszawskim, sprowadzony do Królestwa w 1819 r. przez zamożnego lubelskiego ziemianina Pawła Cieszkowskiego (skoligaconego z wysokimi stołecznymi dygnitarzami, dlatego też mającego możliwość wyjednania dla Montiego prestiżowych zleceń, w tym dekoracji jednej z komnat Pałacu Namiestnikowskiego), zażądał jednak za swoją pracę zbyt wysokiego honorarium ${ }^{55}$. Nie wiadomo, jaka miała być tematyka tych fresków, choć Monti, sam przedstawiający się jako malarz historyczny ${ }^{56}$, specjalizował się w ściennym malarstwie figuralnym (w pałacu Cieszkowskiego w Surhowie wykonał serię scen z przedstawieniami zaczerpniętymi z antycznej mitologii, Biblii oraz historii narodowej, uwzględniając również wizerunek Aleksandra jako dawcy konstytucji), co raczej wykluczało czysto dekoracyjną malaturę. Wiadomo jedynie, że w zamyśle malarza tło miało być złocone ${ }^{57}$, co wpływało na wysoki koszt, świadcząc jednak o artystycznej ambicji dostosowywanej do podniosłego charakteru tego pomnikowego przedsięwzięcia. Gdyby jego dzieło powstało, byłoby ewenementem na skalę europejską, jeżeli chodzi o współcześnie wznoszone świątynie katolickie (sam pomysł wydaje się zresztą nawiązywać do prawosławnego wyznania Aleksandra). Oficjalnym powodem rezygnacji z usług włoskiego artysty był jednak zbyt długi okres powstawania, znacznie przekraczający termin, w którym Aigner obiecywał zakończyć wszystkie prace. Zajączek proponował więc ministrowi oświecenia Stanisławowi Kostce Potockiemu, cieszącemu się autorytetem w kwestiach artystycznych (będących przy tym w gestii jego ministerstwa), powierzenie tego zadania „rodakowi szkoły warszawskiej”. Miało być to „przyjemniejszym” rozwiązaniem zarówno dla ministra, jak i „mieszkańców” stolicy, którzy z tego kościoła mieli korzystać. Namiestnik proponował nawet zorganizowanie konkursu „celem emulacji i zachęcenia do pracy" lokalnych twórców ${ }^{58}$. Ostatecznie jednak żaden konkurs nie doszedł do skutku, a ściany świątyni-pomnika pozostawiono bez dekoracji, choć przecież czasu, ze względu na znacznie przedłużający się proces budowy, było aż nadto.

${ }^{55}$ E. Rastawiecki, Słownik malarzów polskich, tudzież obcych $w$ Polsce osiadłych lub czasowo w niej przebywajacych, t. 2, Warszawa 1851, s. 57-58.

${ }^{56} \mathrm{~W}$ prasowym ogłoszeniu Monti pisał o sobie: „malarz historyczny w sposobie olejnym, a fresco i portretowy”: „Gazeta Warszawska”, 1 V 1819, nr 35 (dodatek).

57 E. Rastawiecki, op. cit., t. 2, s. 58.

58 List F.K. Kosseckiego do S.K. Potockiego, 23 XI 1819, AGAD, Archiwum Publiczne Potockich, sygn. 271, s. 528-529. 
Środki, które udało się zgromadzić, pozwoliły jednak na wyposażenie wnętrza w trzy ołtarze i posadzkę wykonane z krajowego marmuru (materiału, który łączył w sobie pozytywnie rozumianą oszczędność z patriotyczną symboliką), jak również paramenty liturgiczne ze złoconego brązu, odznaczające się zdaniem współczesnego komentatora „pięknością zadziwiającą" ${ }^{59}$. Mimo to stosunkowa skromność oddanej do użytku budowli mogła nieco rozczarowywać, o czym świadczy anonimowy wierszyk w dość kąśliwy sposób wyrzucający Aignerowi, że kościół, choć „drogi”, to „ubogi”, do tego w „kształcie kaplicy” raczej niż monumentalnej świątyni ${ }^{60}$. Autor przewodnika po Warszawie z $1827 \mathrm{r}$. również był dość powściągliwy w ocenie architektury obiektu, chwaląc tylko wybrane detale, takie jak kopuła czy kunsztowne opracowanie elementów porządkowych w portykach ${ }^{61}$. W gruncie rzeczy świątynia stanowiła jednak i tak duże architektoniczne osiągnięcie, będąc pierwszą (i jedyną) dojrzale klasycystyczną i zarazem wolnostojącą budowlą sakralną w stolicy Królestwa, jak najbardziej zasługującą na umieszczenie jej podobizny w graficznym Zbiorze celniejszych gmachów miasta stołecznego Warszawy, opublikowanym przez Leonarda Schmidtnera w 1824 r., a więc jeszcze przed oddaniem jej do użytku ${ }^{62}$.

\section{IV}

Brak satysfakcji z ostatecznego efektu mógł stanowić istotną motywację dla kolejnych inicjatyw, tym bardziej że sam charakter kultu „wskrzesiciela" przeszedł w międzyczasie poważną transformację. W 1818 r., czyli tym samym, w którym zwołano pierwszy sejm Królestwa, polityka Aleksandra wobec nadwiślańskich poddanych wciąż pokrywała się $\mathrm{w}$ powszechnym odbiorze z liberalnymi przepisami nadanej przez niego konstytucji. Natomiast w 1825 r. cesarz-król był już innym człowiekiem: dogłębnie zirytowanym niepojętym dla niego krytycyzmem Polaków, nieprzyzwyczajonych do rządów silnej ręki i traktujących Aleksandra jak tradycyjnego polskiego monarchę, którego działania można było poddawać swobodnej ocenie i do tego się im przeciwstawiać, zamiast z uniżeniem cieszyć się każdym przejawem królewskiej łaski ${ }^{63}$.

59 Ł. Gołębiowski, op. cit., s. 99.

${ }^{60}$ Wiersz cytowany in extenso w: T.S. Jaroszewski, Kościót św. Aleksandra, s. 29-31.

${ }^{61}$ Ł. Gołębiowski, op. cit., s. 99.

62 [L. Schmidtner], Zbiór celniejszych gmachów miasta stołecznego Warszawy, z. 2, Warszawa 1823, tabl. 24, z. 3, Warszawa 1824, tabl. 14, 15.

${ }^{63}$ Na temat relacji rząd-parlament patrz: M. Karpińska, „Nie ma Mikołaja!”. Starania o kształt sejmu w powstaniu listopadowym 1830-1831, Warszawa 2007, s. 43-72; M. Mycielski, 
Nadając Polakom konstytucję, czuł się władnym zmieniać jej postanowienia $\mathrm{w}$ zależności od uznania, co pozostawało w zgodzie $\mathrm{z}$ wyniesionymi przez niego z rosyjskiej tradycji wyobrażeniami o władzy monarszej. Z kolei uświadomieni politycznie i angażujący się w życie publiczne Polacy nie zamierzali, w swojej większości, pogodzić się z coraz bardziej antyliberalnym kursem polityki Aleksandra, trzymając się silnie konstytucji jako niewzruszonego fundamentu narodowego „wskrzeszenia”. W oczach wielu, zwłaszcza ze starszego pokolenia, utworzenie Królestwa stanowiło wszakże ziszczenie wieloletnich marzeń o przywróceniu Polski na mapę Europy, a przyznać się do zawodu nie było łatwo.

Mit „wskrzesiciela” stawał się więc w tej sytuacji coraz bardziej oderwany od rzeczywistości. Jednak znakomitą okazją do jego odświeżenia jako politycznego narzędzia mającego na celu utrzymanie w mocy postanowień konstytucyjnych okazała się śmierć Aleksandra pod koniec 1825 r. Publiczne wyrazy pamięci redukowano od tej pory jedynie do dzieła roku 1815, wypierając późniejszą ewolucję poczynań politycznych cesarza-króla. W ten sposób chciano stawiać Aleksandra jako przykład jego następcy Mikołajowi, wykorzystując deklarowane przez tego ostatniego zobowiązanie do kontynuowania dotychczasowej polskiej polityki starszego brata i jak mantrę powtarzając, że to właśnie konstytucja świadczy o tym, jakie były w tej mierze jego prawdziwe zamiary. Właśnie w tym duchu prezes Senatu Stanisław Kostka Zamoyski wystosował oficjalny adres do Mikołaja I, noszący datę 17 stycznia 1826 r., a więc niedługo po ogłoszeniu przez nowego króla specjalnego manifestu skierowanego do polskich poddanych ${ }^{64}$. Pisząc $w$ imieniu jednej z najwyższych instytucji państwa ${ }^{65}$, Zamoyski łączył się w bólu z powodu śmierci jego poprzednika, podkreślając szczególne przywiązanie Polaków do Aleksandra: „my, którzy skutkiem długiej niełaskawości losu wytrąceni niedawno z rzędu Narodów, winniśmy powrót pierwiastkowego [tj. dawnego] bytu, stałej tylko Woli i Wielkiej duszy naszego WSKRZESICIELA [podkreślenie oryginalne - M.G.K.]”. Równocześnie wskazywał,

Rząd Królestwa Polskiego wobec sejmików i zgromadzeń gminnych 1815-1830, Warszawa 2010, passim. O sejmie 1825 r. patrz: R. Przelaskowski, Sejm warszawski roku 1825, Warszawa 1929.

${ }^{64}$ Pismo S.K. Zamoyskiego w imieniu Senatu Królestwa do Mikołaja I, 17 I 1826, AGAD, I Rada Stanu Królestwa Polskiego (dalej - I RSKP, sygn. 257, s. 30-31.

${ }^{65}$ Co prawda formalna hierarchia urzędów nigdy nie została w Królestwie wprowadzona, jednak precedencja stosowana w trakcie uroczystości najwyższego szczebla, takich jak symboliczny pogrzeb Aleksandra w Warszawie w 1826 r., wskazywała na honorowe pierwszeństwo senatorów wśród wszystkich innych dostojników z wyjątkiem namiestnika, zresztą także będącego członkiem Senatu. Opis żałobnego obchodu, s. XIX-XX, XXV-XXVI. 
że „godło trwałości znaleźć tylko możemy w wysokich pomysłach, jakie TOBIE [podkreślenie oryginalne - M.G.H.] przekazał" Aleksander, ,jakie już odziedziczyłeś tak zaszczytnie i tak szlachetnie objawiłeś", odnosząc się do słów manifestu Mikołaja na temat kontynuacji dotychczasowej polityki brata, która w oczach senatorów oznaczała politykę roku 1815. Pragnąc dowieść tego przywiązania do Aleksandra jako „wskrzesiciela”, senatorowie wyrażali swoje pragnienie, aby powszechne narodowe odczucia (których, zgodnie ze słowami Mikołaja, Senat miał być „tłumaczem [--] nieustannym”) „utrwalone zostały w pomniku poświęconym ukochanej pamięci Króla, którego zgon opłakujemy". Zaznaczano przy tym, że „słabe usiłowania nasze” mogłyby „nie zdołać wznieść się do świetności godnej znakomitego celu, jaki sobie zamierzamy", sugerując brak odpowiednich środków na taki dowód polskiej wdzięczności, który mógłby w pełni odzwierciedlać jej rozmiar. Zarzekał się przy tym, że „i szeląg wdowy niesie piętno swoje wiekom potomnym i Najwyższa Istność przyjmuje w swych świątyniach obok darów okazałych, skromniejsze czci i wdzięczności ludów ofiary". Był to jednak tylko retoryczny zabieg, służący uwypukleniu i swego rodzaju monumentalizacji podstawowej w tym liście kwestii, czyli sposobu, w jaki ten symboliczny „szeląg wdowy" miano pozyskać. Zamoyski kończył bowiem prośbą o zgodę na przygotowanie projektu odpowiedniej ustawy, ustanawiającej fundusz „dostateczny dla wystawienia pamiątce zeszłego Króla i Dobroczyńcy Naszego pomnika, zaświadczającego wdzięczność Narodową". Wydatek miał być więc w zamierzeniu prawdziwie niebagatelny. Kwestię „rodzaju” i „wykonania” pozostawiano przy tym do wyłącznej decyzji monarchy.

List Zamoyskiego został przyjęty przez Mikołaja z zadowoleniem. Car w odpowiedzi z 2/14 lutego 1826 r. pisał o „poznaniu” w hołdzie złożonym pamięci jego brata „cechy niezmiennego poświęcenia się znamionującego” senatorów ${ }^{66}$. Deklarował, że „przeszłość jest dla mnie drogą przyszłości rękojmią", jak również prosił Zamoyskiego o przekazanie wyrazów jego „szczerej życzliwości” wobec reprezentowanej przez niego „pierwszej w kraju magistratury”. Pochwalał „życzenie Senatu, iżby pomnik zupełnie narodowy uwiecznił wdzięczność Polaków ku nieśmiertelnemu ich Ojczyzny Wskrzesicielowi” i „chętnie pozwalał na przedstawiony [--] środek uskutecznienia tego zamiaru”. Widząc w senatorach „tłumaczy” narodowych odczuć, zadecydował, że skoro „wierni poddani Królestwa” są rzeczywiście „połączeni przywiązaniem do ukochanego monarchy”, wszyscy powinni mieć szansę „należeć do uwiecznienia pamiątki ich

${ }^{66}$ List gabinetowy Mikołaja I do S.K. Zamoyskiego, 2/14 II 1826, AGAD, I RSKP, sygn. 257 , s. 32 . 
żalu i uwielbienia", przewidując tym samym ogólnonarodową składkę. W tym celu „upoważnił” Zajączka, aby „wezwał” Radę Administracyjną „do rozważenia projektu do prawa, który na przyszłym sejmie w tym celu ma być wniesiony". Stosowny raport - ale jeszcze nie projekt sporządzony w Komisji Spraw Wewnętrznych, został zatwierdzony na posiedzeniu Rady w tym samym roku, 29 sierpnia $^{67}$.

Ze względów politycznych, na „przyszły sejm” trzeba było czekać aż cztery lata. W tym czasie senatorowie zdążyli zaangażować się w innego rodzaju formę pomnikowej komemoracji Aleksandra, na mniejszą skalę, lecz symbolicznie doniosłą, gdyż dotyczącą ich sali obrad. Ta świątynia odrodzonego bytu państwowego, którą w 1812 r. planowano ozdobić monumentem ku czci Napoleona ${ }^{68}$, teraz miała pomieścić symboliczny „pomnik grobowy” kolejnego „wskrzesiciela”. Zamiast szczątków miał się w nim znaleźć, traktowany jako narodowa relikwia, polski mundur Aleksandra, który już w lutym 1826 r. został przesłany przez Mikołaja Senatowi w geście szczególnego uznania dla senatorów za ich przywiązanie do osoby zmarłego. Sala Senatorska - miejsce o wyjątkowym symbolicznym znaczeniu z punktu widzenia prawnoustrojowego, w którym z okazji otwarcia i zamknięcia obrad spotykały się wszystkie strony biorące udział w pracach ustawodawczych - miała się stać swego rodzaju sanktuarium „wskrzesiciela”. W ten sposób dobitnie podkreślono by monarchocentryczny charakter „wskrzeszonego” państwa. Niestety, nie zachowały się żadne projekty tego pomnika i nie wiadomo nawet, czy powstały. Poza rezolucją Rady Administracyjnej - przyznającej Senatowi specjalny kredyt na ten cel w wysokości 553 złotych - brakuje innych informacji na temat wprowadzania tej idei w życie ${ }^{69}$.

Sprawa właściwego pomnika powróciła w 1829 r., wraz z postępem przygotowań do sejmu. Nieznany obecnie wstępny zarys pomysłu, który minister Mostowski przedstawił na posiedzeniu Rady Administracyjnej w marcu tr., zyskał akceptację królewską w czerwcu, dopiero jednak w listopadzie Rada Administracyjna wezwała Komisję Spraw Wewnętrznych do opracowania szczegółowego projektu ustawy, który miał być następnie przez nią dyskutowany ${ }^{70}$. Takowy, firmowany nazwiskiem Mostowskiego, został przedstawiony 12 stycznia kolejnego roku, wraz

${ }^{67}$ Protokół Rady Administracyjnej, 29 VIII 1826, AGAD, RAKP, sygn. 14, s. 223.

${ }^{68}$ J. Polaczek, op. cit., s. 151 n.; na temat symbolicznego znaczenia Sali Senatorskiej w nieco wcześniejszym okresie patrz: M. Getka-Kenig, Ojcowie „wskrzeszonej” ojczyzny. Senat w rzeczywistości społeczno-politycznej Księstwa Warszawskiego, Warszawa 2013, s. 181.

${ }^{69}$ Protokół Rady Administracyjnej, 28 II 1826, AGAD, RAKP, sygn. 14, s. 52.

70 Protokół Rady Administracyjnej, 17 III 1829, 27 VI 1829, 21 XI 1829, AGAD, RAKP, sygn. 17, s. 124, 301, 593. 
ze szczegółowym uzasadnieniem, czyli „Powodami do projektu”71. Jego treść poświadcza, że władze Królestwa dążyły do dalszego umacniania rezurekcyjnego mitu, gruntującego przekonanie o niezrównanych zasługach Aleksandra na rzecz Polaków, co miało wyrażać się w przekraczaniu tradycyjnych (i nieadekwatnych do swojego przedmiotu) praktyk komemoracyjnych. Projektodawca odrzucał bowiem „wytworne dzieła sztuki, posągi i pomniki ze spiżu lub głazu” jako te, które co prawda „zajmować mogą okazałością swoją, lecz nie przemawiają do serca, nie wzbudzają tkliwego uczucia i płonne tylko czynią wrażenia [podkreślenie moje - M.G.K.] na tych, którzy codziennie na nie patrzą"72. Tym, co w lepszy sposób miało wyrażać polskie uczucia wobec Aleksandra, był „żyjący dowód wdzięczności”73, a więc

zakład wiecznotrwały dający przytułek zubożałym, sprowadzający zepsutych na drogę obowiązków towarzyskich i przyczyniający się do dobra narodu przez umniejszenie liczby ubogich i przez ochronienie od szkodliwego wpływu ich nędzy i demoralizacji, taki zakład uczucie wdzięczności ku temu, komu jest poświęcony, zawsze żywić będzie przez samo doznawanie korzyści, które z niego wypływają, i będzie poniekąd wiecznym odnawianiem tych dobrodziejstw, które za życia swego na ludzi chciał zlewać ${ }^{74}$.

Tak wyraźny nacisk na emocjonalny stosunek Polaków do ich „wskrzesiciela”, kłócący się z bezdusznością tradycyjnych pomników, nie powinien zaskakiwać. Nie był niczym nowym, towarzysząc rozmaitym wypowiedziom dotyczącym zarówno Aleksandra, jak i wcześniej Napoleona i znajdując swój wyraz również w projektach pomnikowych z okresu Księstwa. Należy pamiętać o przywoływanym już we wstępie planowanym pomniku cesarza Francuzów pod Kaliszem, który oprócz kolumny z jego posągiem (wzorowanej na rzymskim monumencie Trajana) uwzględniał jako swój integralny składnik dwa małe domy (z ogrodami) dla wysłużonych weteranów - ideowe pokrewieństwo jawi się tutaj dość wyraźnie ${ }^{75}$.

71 „Projekt pomnika błogosławionej pamięci Aleksandra 1go Cesarza Wszech Rosji Króla Polskiego poświęconego”, AGAD, I RSKP, sygn. 257, s. 6-7; „Powody do projektu pomnika mającego uwiecznić pamięć wskrzesiciela Narodu Polskiego", ibidem, s. 8-15. Patrz również: protokół Rady Administracyjnej, 12 I 1830, AGAD, RAKP, sygn. 18, s. 33.

72 „Powody do projektu pomnika”, s. 8.

73 „Projekt pomnika”, s. 6.

74 „Powody do projektu pomnika”, s. 8.

75 „Gazeta Poznańska”, 17 VIII 1808, nr 66; patrz również: projekt autorstwa C.P. Aignera, Luwr, Cabinet des dessins, Fonds des dessins et miniatures, Réserve des grands albums, RF 30164.5, Recto. 
Nowe było natomiast sprowadzenie tego ostatniego elementu do pozycji jednego z wielu składających się na infrastrukturę pomnika, który w tym przypadku pojmowano nie jako budynek, ale jako cały kompleks wraz z zamieszkującą go społecznością. Projekt przewidywał, że na terenie owej osady, nazwanej Aleksandrynem, wprawdzie ustawi się „dzieła sztuki”, które „wyobrażą rysy żałowanego monarchy”, byłby to jednak jedyny tradycyjny środek pomnikowego wyrazu. Miały się tam również znajdować „kaplice pod wezwaniem śgo Aleksandra wystawione i poświęcone [--] rozmaitym wyznaniom chrześcijańskim"76. Potencjalnie zróżnicowana religijnie społeczność tej osady miała więc zapewnioną odpowiednią posługę duchową, służącą jej formacji moralnej, która również składała się na proces społecznej reedukacji. Jej ekumeniczny charakter - dający się zaobserwować również w przypadku innych pośmiertnych hołdów ku czci cesarza ${ }^{77}$ - wyraźnie akcentował uniwersalny (ogólnospołeczny) wymiar zarówno zasług Aleksandra, jak i wdzięczności Polaków. Z drugiej strony, podobnie jak w przypadku kościoła z placu Trzech Krzyży, wykorzystywanie osoby św. Aleksandra w subtelny sposób sakralizowało kult samego „wskrzesiciela”.

Centralnym elementem tej pomnikowej przestrzeni był „obszerny dom zarobku i schronienia” oraz sąsiadująca z nim „osada wolna dla tysiąca rodzin, przeznaczona na to, aby w każdym czasie wsparcie dla niedoli przytułek dla skruchy, prace i pożywienie dla ubóstwa zapewnić zdołały"78. Cesarsko-królewskie podobizny i poświęcone jego kanonizowanemu alter ego świątynie miały więc identyfikować to przedsięwzięcie z osobą Aleksandra, wzbogacając jego wymowę o symbolikę piękna i sakralne odwołania, jednak w takim stopniu, który nie przesłaniałby przewodniego wątku ideowego, jakim było „poniekąd przedłużenie w przyszłe wieki tych czynów miłosierdzia, którymi błogosławionej pamięci Aleksander 1szy chlubne życie swoje zdobił"79. Miano tutaj na myśli „skromne dobroczynności cnoty”, które „nieodżałowany monarcha wskrzesiciel Królestwa Polskiego” miał „lubić wykonywać [--]

76 „Projekt pomnika”, s. 6-7.

77 Przykładem luksusowa publikacja Opisu żałobnego obchodu po wiekopomnej pamięci Najjaśniejszym Aleksandrze (patrz przyp. 47), w której oprócz wstępu oraz spisu wszystkich uczestników ceremonialnego pochodu z symbolicznymi marami uwzględniono również kazania i mowy, które wygłosili z tej okazji duchowni katolicki, ewangelicko-augsburski i ewangelicko-reformowany, a także reprezentant społeczności żydowskiej. Ponadto, zamieszczono tam również ryciny ukazujące żałobne nabożeństwa ku czci Aleksandra, zorganizowane przez katolików, ewangelików i Żydów.

78 Ibidem, s. 6.

79 „Powody do projektu pomnika”, s. 8. 
w chwilach wolnych od ważnych zatrudnień, dobro narodów na celu mających" ${ }^{80}$. Tak jak za życia dobroczynność Aleksandra stanowiła - w wizji projektodawcy - pars pro toto jego działalności na rzecz powszechnego dobra, tak samo po śmierci zamierzano go uczcić poprzez wyróżnienie tej jednej jego aktywności, która mogła przy tym symbolizować miłosierdzie innego wymiaru, czyli to, którym Aleksander odznaczył się w stosunku do narodu polskiego. Wszakże projektodawca wprost obdarzał „wielkomyślnego wskrzesiciela" - kończąc wprowadzający akapit projektu - mianem „przyjaciela ludzi”"1. Jak pamiętamy, pokrewny wątek pojawił się już w 1816 r., jednak dopiero teraz wysunął się on na zdecydowanie pierwszy plan, co znalazło swój wyraz w formie upamiętnienia.

Ten niecodzienny pomysł nie brał się z niczego. Waga, którą projektodawcy przykładali do tych „skromnych dobroczynności cnoty”, przejawiała charakterystyczne dla omawianej epoki zainteresowanie losem najuboższych, o których troszczyć miało się nie tylko duchowieństwo, ale i świeccy, np. członkowie Warszawskiego Towarzystwa Dobroczynności, grupującego przedstawicieli społecznej elity i mającego swojego pierwszego prezesa w osobie samego Adama Jerzego Czartoryskiego, brata pomysłodawczyni, Zofii Zamoyskiej (żony Stanisława Kostki, prezesa Senatu ${ }^{82}$. Ponadto, na poziomie instytucjonalnym dobroczynnością parały się również loże wolnomularskie (zdelegalizowane jednak, tak jak reszta towarzystw tajnych, w 1821 r.). Pośmiertna sława „wskrzesiciela" Polaków miała być od tej pory powiązana nie tylko z tradycyjnie rozumianą pomocą ubogim, ale i z nowoczesnymi (i nie mającymi wiele wspólnego z kościelną tradycją podchodzenia do tego tematu) postulatami „wytępienia żebractwa”, „zapobiegania pomnażania się liczby ubogich" i znajdowania pracy dla tych „zdolnych" do jej podejmowania, ale z różnych przyczyn „niechcących pracować lub niemogących znaleźć zatrudnienia"83. Kult pracy jako czynnika odpowiedzialnego za prawidłową sytuację społeczeństwa ukierunkowywał sposób, w jaki wielkość Aleksandra miała być odczytywana - jako „wskrzesiciela” państwa-narodu będącego dobrem wspólnym, a więc takim, o którego pomyślny stan wszyscy powinni się troszczyć poprzez indywidualny wysiłek, nawet jeżeli mieliby być do niego przymuszeni.

W idei stojącej u podstaw tego pomnikowego projektu łatwo doszukiwać się inspiracji rozprawą $O$ ubóstwie $i$ ubogich autorstwa Fryderyka

${ }^{80}$ Ibidem, s. 8.

81 „Projekt pomnika”, s. 6.

${ }^{82}$ H. Markiewiczowa, Działalność opiekuńczo-wychowawcza Warszawskiego Towarzystwa Dobroczynności, Warszawa 2012, s. 58-61.

83 „Powody do projektu pomnika”, s. 9. 
Skarbka (dedykowaną Z. Zamoyskiej, „tej, której imię wdzięczność ubogich wiecznej pamięci przekaże"), opublikowaną w Warszawie w 1827 r. Ten profesor Uniwersytetu Warszawskiego i członek Towarzystwa Przyjaciół Nauk krytykował w niej dotychczasowy brak zainteresowania tym problemem ze strony władz rządowych, przekonanych najwyraźniej o tym, że „prawodawstwo i administracja wcale zajmować się nie powinny, ponieważ lepiej jest to staranie prywatnej dobroczynności zostawić”, gdyż w rezultacie „rozwijają się” wśród bogatszych „piękne przymioty miłosierdzia, dobroczynności i wdzięczności, że z pomieszania ubogich i bogatych wypływają pewne moralne korzyści, a może nawet i sposobność ustanowienia pewnego zrównania majątków" ${ }^{84}$. Taki sposób myślenia prowadził jednak zdaniem Skarbka do podtrzymywania zjawiska ubóstwa. Nazywając taką postawę „źle zrozumianą gorliwością o rozkrzewianie cnót towarzyskich i przesadą w szukaniu zasługi w tkliwych i dobroczynnych uczuciach", skarbek postulował, aby opieka nad ubogimi została objęta państwowym patronatem, gdyż tylko w ten sposób można prawdziwie rozwiązać ten problem, sprzeciwiający się ,jednemu celowi głównemu”, do którego zmierza „życie towarzyskie narodów [--] od pierwszych zawiązków społeczeństwa”, czyli do bogactwa i „wypływającej z niego oświaty" 85 . Podawał przy tym konkretne rozwiązanie, jakim miała być właśnie osada dla ubogich, wzorowana na tej założonej w 1818 r. w Holandii i nazwanej Friedericks-oord ${ }^{86}$. Ten sam model został wskazany również w opracowanych przez Komisję Powodach, stawiających tezę, że

po wielokrotnym mniej więcej niepomyślnym doświadczeniu w różnych krajach Europy rozmaitych środków wytępienia żebractwa i utrzymywania ubogich zdolnych do pracy udało się Towarzystwu Dobroczynności w Holandii natrafić na właściwszą drogę i dowieść przez wypadki dziesięcioletniego doświadczenia, iż najmniej kosztownym, a zarazem najskuteczniejszym sposobem opatrywania potrzeb ubogich i przywiedzenia moralnej poprawy tułaczy i żebraków było zakładanie z nich osad rolniczych, w których by nad własnym utrzymaniem pracowali ${ }^{87}$.

${ }^{84}$ F. Skarbek, 0 ubóstwie i ubogich, Warszawa 1827, s. 4.

85 Ibidem, s. 1.

${ }^{86}$ Ibidem, s. 107. Na temat holenderskiej osady (a właściwie grupy osad) omówionej w kontekście kluczowego w tym przypadku kolonialnego doświadczenia ówczesnych Holendrów patrz: A. Schrauwers, The „Benevolent” Colonies of Johannes van den Bosch: Continuities in the Administration of Poverty in the Netherlands and Indonesia, "Comparative Studies in Society and History”, t. 43, 2001, nr 2, s. 298-328.

87 „Powody do projektu pomnika”, s. 9. 
Warto w tym miejscu zaznaczyć, że sama idea upamiętnienia Aleksandra poprzez osiedle miała już wówczas swój precedens pod postacią rosyjskiej kolonii Alexandrowka na terenie Poczdamu, którą powołał do życia w roku 1826 król pruski Fryderyk Wilhelm III ,jako trwały pomnik pamięci o więzach głębokiej przyjaźni pomiędzy mną i najbłogosławieńszym cesarzem Aleksandrem rosyjskim"88. Trudno jednak powiedzieć, czy w ogóle, a jeśli tak, to w jakiej mierze ten pomnik osobistej (ale odznaczającej się ważkimi politycznymi skutkami) przyjaźni pomiędzy monarchami wpłynął na polskich pomysłodawców. O tym, czy mógł on np. przekonywać ich o stosowności tej tak wielce niekonwencjonalnej formy upamiętnienia (wszakże z Friedericks-oord, która charakteru pomnikowego nie miała, czerpano tylko koncepcję funkcjonowania osady ubogich), przy braku źródeł możemy dyskutować jedynie hipotetycznie.

Spośród obszernej grupy osób dotkniętych ubóstwem „żyjący” pomnik ku czci Aleksandra dotyczyć miał wyłącznie reprezentantów właściwego marginesu społecznego, a więc tych, których trzeba było przymusić do pracy, aby mogli z pożytkiem żyć w społeczeństwie, mianowicie: tułaczy, żebraków, „ludzi złych skłonności lub nie dosyć ustalonych jeszcze w dobrych chęciach mających siły potrzebne, a nie mających ani zdatności, ani chęci do pracy, i na koniec dla takich, którzy już doszli do ostatniej nędzy, a mogliby się z niej jeszcze wydźwignąć za pomocą własnej pracy"89. Cesarsko-królewski dar narodowego „wskrzeszenia” miał więc od tej pory kojarzyć się z tym, co dotąd wydawało się niemożliwe $-\mathrm{z}$ uleczeniem tej z pozoru nieuleczanej choroby ludzkości, której jedynie przy pomocy (działającego z monarszego upoważnienia) rządu, jak przekonywał Skarbek, można skutecznie zaradzić. Projekt zakładał, że „cały naród [podkreślenie - M.G.K.]”, a więc „wszyscy mieszkańcy kraju [podkreślenie - M.G.K.] stosownie do możności swojej przykładać się powinni” do „wyniesienia takowego pomnika”. W tym gronie mieli znaleźć się przede wszystkim ci, których dochody poddawano opodatkowaniu (jak obywatele ziemscy i miejscy, ludzie „przemysłu rzemieślniczego i handlowego" oraz urzędnicy wojskowi i cywilni, nie wyłączając również pozbawionych pełni praw publicznych „starozakonnych"), i których składka - traktowana jako patriotyczny obowiązek, a więc nie dobrowolna - była z góry ustalona w zależności od wysokości

88 „als ein bleibendes Denkmal der Erinnerung an die Bande der innigen Freundschaft zwischen Mir und des höchst seligen Kaisers Alexander von Rußland Majestät". Rozkaz królewski dla dowódcy pierwszego regimentu piechoty gwardii z 10 IV 1826 r. Na temat kolonii Alexandrowka patrz: B.B. Altendorf, Die russischen Sänger des Königs und die Kolonie Alexandrowka in Potsdam, Berlin 2004, s. 23-43.

${ }^{89}$ „Powody do projektu pomnika”, s. 12. 
opłacanego podatku. Do współudziału zachęcano jednak także ogół pozostałych $^{90}$. Grono zobowiązanych do wdzięczności (i zarazem mających troszczyć się o prawidłowy rozwój całego społeczeństwa) zostało więc zdefiniowane tak szeroko, jak tylko było można. Potrzebną sumę przewidywano zebrać w ciągu sześciu lat ${ }^{91}$.

Dalsze losy tego projektu znane są tylko wyrywkowo, ze względu na braki w archiwaliach dotyczących instytucji biorących udział w pracach legislacyjnych. Naniesiono na nim pewne poprawki w wyniku dyskusji w Radzie Administracyjnej, a następnie przekazano do ministra skarbu i przychodu, który miał go zaprezentować na sejmie ${ }^{92}$. W tym czasie doszło do zmian w szczegółach finansowania (dokładnie ustalono wysokość składek oczekiwanych od poszczególnych grup podatników, jak również skrócono czas ich uiszczania do czterech lat, w ciągu których miano zebrać blisko $6,5 \mathrm{mln}$ złotych) ${ }^{93}$, a także - i przede wszystkim - zdecydowano się zrezygnować nie tylko z idei Mostowskiego, ale w ogóle z jakiegokolwiek precyzowania wizji „Pomnika Wdzięczności Narodowej”, zastępując dotychczasowy projekt ustawy innym, dotyczącym wyłącznie kwestii zbierania pieniędzy na ten cel. W przedmiocie „rodzaju pomnika” przewidywano jedynie, że zostanie on „oznaczony” przez oddzielne „postanowienie królewskie” 94 . Formę upamiętnienia zdecydowano się więc pozostawić wyłącznej decyzji Mikołaja, bez poddawania jej sejmowej sankcji, zresztą zgodnie z oryginalną propozycją prezesa Senatu. Być może cesarz-król chciał poczekać do momentu, kiedy zbierze się odpowiednio znaczną sumę, aby uniknąć sytuacji, w której raz oficjalnie powzięte i firmowane rządowym autorytetem zobowiązania kompromitowałby odkładany w nieskończoność termin finalizacji, jak również nieprzystający do początkowej ambicji efekt.

Władze wyraźnie nie uważały za konieczne pytać się narodu (w osobach jego reprezentantów) o sposób, w jaki chciałby on upamiętnić swojego dobroczyńcę. Co prawda, zarzucony projekt Mostowskiego, ze względu na swoją precyzję, również nie pozostawiał zbyt szerokiego pola inwencji twórczej, jednak przynajmniej podlegałby głosowaniu. Rząd był, jak widać, przekonany, że ma pełne prawo wyręczać naród w tej sprawie,

90 Ibidem, s. 14.

${ }^{91}$ Ibidem, s. 7.

92 Protokół Rady Administracyjnej, 12 I 1830 oraz 21 V 1830, AGAD, RAKP, sygn. 18, s. 33, 358.

93 Projektowany obrachunek składki, który przedstawiono sejmowi: AGAD, I RSKP, sygn. 257, s. 33.

94 „Projekt do ustawy sejmowej względem wzniesienia Pomnika Wdzięczności Narodowej dla Wskrzesiciela Polski”, AGAD, I RSKP, sygn. 257, s. 26-27. 
tak jak czynił to zresztą w poprzednich przypadkach. Wiadomo, że parlamentarzyści domagali się wyjaśnień w tej kwestii ${ }^{95}$, choć ze względu na zniszczenie diariusza sejmowego z $1830 \mathrm{r}$. nie sposób powiedzieć, czy przedstawiali też własne projekty i co dokładnie proponowali. Już po uchwale sejmowej i poza parlamentem została upubliczniona w druku pojedyncza propozycja przyszłego przeznaczenia zbieranych funduszy, która wyszła od posła Romana Sołtyka (tego samego, który kilka miesięcy później zgłosił na sejmie powstańczym wniosek o detronizację Mikołaja $)^{96}$. Co znamienne, również on przewidywał dobroczynny charakter komemoracji („,bolesna, nienagrodzona byłaby, gdyby składka natchniona wdzięcznością nie miała najdobroczynniejszych celów"), z tą jednak odmianą, że pieniądze miano wydać na obdarzenie włościan „zupełną własnością ziemi” (tj. miano je zainwestować w wykup ziemi, co w ciągu stu lat miało zakończyć się pełnym uwłaszczeniem chłopów). Jak widać, projekt Mostowskiego przejawiał więc szerzej podzielaną wrażliwość i wyobrażenie o społecznym postępie, z którym rząd chciał powiązać kult „wskrzesiciela”. Zważając na fakt, że Sołtyk kierował swoją suplikę właśnie do rządzących, nie można wykluczyć, że wyszedł on z tym pomysłem z czysto koniunkturalnych powodów. Bardziej niż na uczczeniu Aleksandra (należał do grona posłów mających zdecydowanie negatywne zdanie o rządzie Królestwa ${ }^{97}$, i zresztą vice vers ${ }^{98}$ ) mogło mu po prostu zależeć na zmianie sytuacji polskich chłopów, co było zgodne z jego demokratycznymi przekonaniami, jak i majątkowym interesem (uwłaszczenie miało wszakże wzmocnić przemysł, którym sam się parał w swoich dobrach ziemskich).

Członkowie Izby Poselskiej jednogłośnie zaaprobowali projekt samej składki na pomnik ${ }^{99}$, przedtem poddając go jednak pewnym korektom, które zostały zgłoszone przez komisję sejmową. Świadczy o tym odezwa wystosowana do senatorów przez jednego z reprezentantów rządu, zapewne samego ministra Franciszka Ksawerego Druckiego-Lubeckiego,

${ }^{95}$ Rezydent pruski Julius Schmidt donosił z Warszawy dnia 7 czerwca 1830 r.: „der Minister [Drucki-Lubecki] jede Mitteilungen über die Art der Verwendung jener Summen mit der Erwiderung zurückwies: dass der Monarch sich vorbehalten habe das Nötige diserhalb zu bestimmen". Cyt. za: Korespondencja Lubeckiego z ministrami i sekretarzami stanu Ignacym Sobolewskim i Stefanem Grabowskim, red. S. Smolka, t. 3: 1827-1830, Kraków 1909, s. 381-382 (przyp. 7).

96 „Kurier Warszawski”, 26 VI 1830, nr 169; 19 VII 1830, nr 191.

97 W. Zajewski, Sołtyk Roman (1790-1843), PSB, t. 40, Warszawa 2000-2001, s. 420-421.

${ }^{98}$ M. Mycielski, op. cit., s. 276.

${ }^{99}$ Ustawa sejmowa z 28 VI 1830 „względem wzniesienia pomnika wdzięczności dla wskrzesiciela Polski, dawcy Konstytucji, wiekopomnej pamięci Cesarza i Króla Aleksandra I", w: Dziennik Praw Królestwa Polskiego, t. 13, [Warszawa 1831-1832], s. 109-115. 
który wcześniej prezentował projekt posłom i deputowanym ${ }^{100}$. Wspominał on ponadto o "lękach" bardzo poważnie podchodzących do tej sprawy członków owej komisji, czy będąc „zniewolonymi zamknąć w ścisłych obrębach uchwały całą rozciągłość nieograniczonej wdzięczności narodu”, pomimo ,ich uwagi i starania, obrane [--] środki w zupełności uczuciem Narodu podołają"101. Warto w tym miejscu przywołać relację senatora-kasztelana Antoniego Ostrowskiego - uczestnika tych obrad, notującego swoje wrażenia i przemyślenia w pisanym na bieżąco prywatnym dzienniku - która jest szczególnie ciekawa ze względu na fakt, że zdradza osobiste nastawienie do tego przedsięwzięcia jednego z późniejszych powstańców (generała i dowódcy Gwardii Narodowej w stolicy) i dożywotnich emigrantów. W swoich prywatnych zapiskach przyszły sygnatariusz aktu detronizacji Romanowów wielokrotnie z szacunkiem wspominał o „błogiej pamięci” Aleksandrze, nie szczędząc również ciepłych słów pod adresem jego następcy Mikołaja, wyrażając swoje przekonanie o jego dobrych intencjach w stosunku do polskich poddanych ${ }^{102}$. Uwielbienie dla królewskiego majestatu miało jednak swoje ściśle zakreślone granice. Wdzięczność za „wskrzeszenie”, na której zasadzała się wierność Polaków wobec monarchy, nie mogła bowiem oznaczać własnego upodlenia, gdyż to godziłoby w poczucie narodowej wartości. Dlatego też pisząc o „zapale”, z jakim Izba Poselska miała przyjąć wniosek o pomniku, nie krył zniesmaczenia „okolicznością”, która „zepsuła nieco oznaki harmonii" wśród parlamentarzystów, mając na myśli mowę posła siennickiego Stanisława Jezierskiego ${ }^{103}$. W przekonaniu Ostrowskiego ten ostatni „najniepotrzebniej” wystąpił z „przygotowaną a bodajby dla własnej jego rozsądku sławy nie wyrzeczoną mową, w której zagłębiając się w powody wdzięczności ku monarsze, miał poniżać przeszłość, przyznawać się do nicości narodu", sugerując - o ile nie wprost mówiąc że ,jakoby Aleksander heroicznego dopełnił czynu, podając rękę narodowi już w gruzach zagrzebanemu, potyranemu i w popioły, o które by nikt nie dbał, zamienionemu”. Taka interpretacja zasług zmarłego cesarza wywołała „szmer powszechnego nieukontentowania”, którego powodem było nie tylko dzielone przez parlamentarzystów przekonanie o wcale nie aż tak tragicznej sytuacji Polaków w 1815 r. Ostrowski zaznaczał bowiem, że nawet gdyby Jezierski miał rację, nie powinien

100 Program sejmu 1830 r., AGAD, Archiwum Zamoyskich (dalej: AZ), sygn. 90, s. 244.

101 Odezwa do Senatu, I RSKP, sygn. 257, s. 29.

102 Patrz: A. Ostrowski, „Pamiętnik sejmu 1830 r.”, AGAD, Archiwum Ostrowskich z Ujazdu, sygn. 144, s. 41.

${ }^{103}$ Ibidem, s. 100-102. 
poruszać tego tematu na forum publicznym, gdyż sprzeciwiało się to zasadom „zdrowej polityki”. Jak bowiem przyznawał, „szlachetniej jest dla naszego narodu twierdzić, że łaski rzeczywiste, których doznaliśmy od naszego prawodawcy i dobroczyńcy, bardziej początkują w powodach nabytej w bojach i pokój ceniącej dla ojczyzny sławy aniżeli w litości, na którą z strony Rosji [my] bynajmniej nie zasłużyli". Jego zdaniem, Polacy „ani zmniejszać, ani zwiększać nie powinni najwyższych z strony naszej pojęć wdzięczności dla pamięci tego niepospolitej dobroci monarchy, który z niepospolitą delikatnością i skromnością podawał rękę nieszczęśliwemu, lecz nie poniżonemu ludowi".

Projekt ostatecznie nie został zrealizowany z powodu powstania (pierwsze fundusze miano zbierać w 1831 r.). Jeszcze zanim ten moment nastąpił, o senackiej idei „pomnika wdzięczności narodowej” zdążono publicznie przypomnieć w związku z akcją na rzecz odnowy Zamku wawelskiego. Niedługo po zakończeniu obrad parlamentarnych specjalna delegacja Senatu skierowała odezwę "do rodaków” (do rozprowadzenia wśród senatorów oraz urzędników), wzywającą do finansowego przyłożenia się do inicjatywy podjętej przez Senat Wolnego Miasta Krakowa i mającej na celu „dźwignienie i ocalenie tej nader szacownej świetnego niegdyś bytu narodowego pamiątki”, „okazałego niegdyś Piastów i Jagiełłów mieszkania”, którego postępująca ruina groziła „zasypaniem gruzami świętych grobów królów i bohaterów naszych" (co do tych ostatnich, miano tu zapewne głównie na myśli niedawno pochowanych na Wawelu księcia Józefa oraz Kościuszkę) ${ }^{104}$. Jak przekonywali podpisani (wojewoda A.J. Czartoryski, kasztelan Michał Kochanowski oraz sekretarz Senatu Julian Ursyn Niemcewicz), ,też same ręce, które wskrzesicielowi bytu” i zarazem „swobód naszych wznoszą” teraz „pomnik wdzięczności”, jak najbardziej powinny „przyłożyć się” niemniej „chętnie do zachowania dla następnych pokoleń starożytnego chwały narodowej pomnika"105. Oba projekty składkowe łączyło ścisłe pokrewieństwo ideowe. Odbudowa Wawelu jako symbolu narodowej sławy miała stanowić efekt „wskrzeszenia”. Co ciekawe, za odwołaniem do „wskrzesiciela” stała tutaj nieco koniunkturalna (w całej swojej szczytności) motywacja. Albowiem ci, którzy składali się na pomnik Aleksandra, mieli stawać się zakładnikami własnego patriotyzmu, nie mogąc odmówić wsparcia dla drugiego szczytnego przedsięwzięcia, niejako wynikającego z pierwszego.

104 Odezwa w sprawie remontu Zamku na Wawelu, 10 VII 1830, AGAD, AZ, sygn. 90 , s. 276.

105 Odezwa do senatorów, 10 VII 1830, AGAD, AZ, sygn. 90, s. 276. 
Podsumowując, rządowe projekty pomnikowe ku czci Aleksandra I wskazują na chęć ugruntowania wizji „wskrzeszenia” roku 1815 jako epoki przynoszącej ze sobą postęp zarówno cywilizacyjny, jak i moralny. Odwołując się do wieloznaczności materialnych form wyrazu, pomnikowy dyskurs „wskrzeszenia” opierał się na swego rodzaju skojarzeniowych amalgamatach, łączących w spójne całości rozmaite pozytywne idee, które miały określać tożsamość Królestwa jako „wskrzeszonej” Polski: np. triumf - wolność polityczna - rozwój i upiększanie miasta, świętość - rozwój i upiększanie miasta - zasługi obywatelskie, praca miłosierdzie - świętość - paternalizm - społeczny dobrobyt. Charakterystyczne przejście od bramy triumfalnej, przez kościól, do osady pracy dla reprezentantów marginesu społecznego unaoczniał ewolucję w sposobie rozkładania podstawowych akcentów w oficjalnym kulcie „wskrzesiciela", stanowiącą odpowiedź na zmieniający się kontekst polityczny i postępujący kryzys prestiżu „wskrzeszonego” państwa. Co prawda wątek miłosierdzia i wspaniałomyślności zaznaczał się tutaj od początku, jednak jego wyeksponowanie było odmienne na różnych etapach. Łagodzeniu królewskiego wizerunku - od militarnego triumfatora przejawiającego miłosierdzie do filantropa pozbawionego jakichkolwiek cech zwycięzcy - znamiennie towarzyszyło zdecydowane umacnianie się nadwiślańskiego rządu na pozycjach autokratycznych. Co więcej, zgodnie z deklaracjami ministra-projektodawcy, decyzja o rezygnacji z tradycyjnej formy upamiętnienia na rzecz „żyjącego dowodu wdzięczności” wynikała z jej nieprzystawalności do wielkości Aleksandra jako dobroczyńcy Polaków i zarazem wdzięczności tych ostatnich. Idea założenia osady Aleksandryn hiperbolizowała zasługi cesarza-króla w stopniu o wiele większym niż poprzednie pomysły, co warunkowała o wiele trudniejsza niż w 1816 (kiedy chciano budować bramę) czy 1818 r. (kiedy zaczęto budowę kościoła) sytuacja na linii rządzący-rządzeni ${ }^{106}$.

106 Warto tutaj wspomnieć, że w ostatnich latach przed wybuchem powstania listopadowego pojawiła się jeszcze jedna publiczna inicjatywa budowy pomnika ku czci Aleksandra. Nie miał to być jednak pomnik od narodu, ale od „wojska polskiego w hołdzie wdzięczności” za opiekę ze strony zmarłego monarchy. Z nielicznych informacji, jakie posiadamy na temat jego formy, wiadomo, że chciano wznieść obelisk z marmuru pochodzącego z Finlandii (nota bene, jest to dość niespotykany materiał w przypadku inwestycji komemoracyjnych w Królestwie, gdzie starano się korzystać z własnych zasobów tego kamienia), który miano ozdobić figurami alegorycznymi o nieznanej obecnie treści. Oprócz napisu dedykacyjnego miało się na nim znaleźć także wezwanie do Boga o modlitwę za duszę zmarłego monarchy. Z powodu braku zachowanych źródeł 


\section{Streszczenie}

Przedmiot analizy stanowią projekty i zarazem okoliczności budowy pomnika (pomników) ku czci cesarza rosyjskiego Aleksandra I jako „wskrzesiciela” Polski, które były związane z rządem konstytucyjnego Królestwa Polskiego (1815-1830). Jest to przyczynek do badań nad fenomenem ideologii „wskrzeszenia” Polski pod postacią Królestwa Polskiego, powstałego na mocy decyzji Kongresu Wiedeńskiego, ale z woli Aleksandra I.

Rządowe projekty pomnikowe ku czci Aleksandra I wskazują na chęć ugruntowania wizji „wskrzeszenia” roku 1815 jako epoki przynoszącej ze sobą postęp zarówno cywilizacyjny, jak i moralny. Odwołując się do wieloznaczności materialnych form wyrazu, pomnikowy dyskurs „wskrzeszenia” opierał się na skojarzeniach, łączących w spójne całości rozmaite idee, które miały określać tożsamość Królestwa jako „wskrzeszonej” Polski: np. triumf - wolność polityczna — rozwój i upiększanie miasta, świętość - rozwój i upiększanie miasta - zasługi obywatelskie, praca - miłosierdzie - świętość - paternalizm - społeczny dobrobyt. Charakterystyczne przejście od bramy triumfalnej, przez kościół, do osady pracy dla reprezentantów marginesu społecznego wskazywał na ewolucję w sposobie rozkładania akcentów w oficjalnym kulcie „wskrzesiciela”, stanowiącą odpowiedź na zmieniający się kontekst polityczny i postępujący kryzys prestiżu „wskrzeszonego” państwa. Co prawda wątek miłosierdzia i wspaniałomyślności zaznaczał się tutaj od początku, jednak jego wyeksponowanie było odmienne na różnych etapach. Łagodzeniu królewskiego wizerunku - od militarnego triumfatora przejawiającego miłosierdzie do filantropa cech tych pozbawionego towarzyszyło zdecydowane umacnianie się nadwiślańskiego rządu na pozycjach autokratycznych.

\section{Government Undertakings Concerning Monuments in Honour of Alexander I and the Ideology of the "Resurrection" of Poland, 1815-1830}

This analysis deals with the projects and circumstances of erecting monuments in honour of Emperor Alexander I of Russia, conceived as the "resurrector" of Poland, and involving the government of the constitutional Kingdom of Poland

na temat tej inicjatywy, można jedynie hipotetycznie domniemywać, że w założeniu konkurowała ona z projektem senacko-rządowym i miała na celu podkreślać szczególne znaczenie armii w Królestwie Polskim. Do takiej hipotezy skłania wiedza o negatywnym nastawieniu wielkiego księcia Konstantego do cywilnego aparatu władzy i charakterystyczna dla niego chęć wywyższania wojskowych w zestawieniu z urzędnikami. Przywołane powyżej podstawowe informacje o tym pomniku (który w zmienionej formie doczekał się realizacji już po powstaniu, i stanął na terenie Cytadeli warszawskiej) pochodzą z artykułu Czesława Żelaznego, Geneza obelisku w Cytadeli: na marginesie sprawy wzniesienia pomnika Traugutta, „Polska Zbrojna”, 1923, nr 291, s. 3. 
(1815-1830). This text is a contribution to research into the ideology of "resurrecting" Poland in the form of the Kingdom of Poland established upon the basis of a decision made at the Congress of Vienna but determined by Alexander I.

The official projects for a monument commemorating the tsar indicate a readiness to consolidate a vision of the "resurrecting" year of 1815 as ushering in an era of civilizational and moral progress. By referring to the ambiguity of material forms of expression, the "resurrection" discourse was based on associations which merged into cohesive entities various positive ideas which were to express the Kingdom's identity as a resurrected Poland, such as triumph, political liberty, the development or embellishment of towns, civic merits such as labour, compassion, sanctity, paternalism and social welfare. A characteristic shift from a triumphal gate to a settlement offering work to representatives of the social margin indicated an evolution in the way fundamental accents were distributed within the official cult of the "resurrector", thus comprising a response to the changing political context and the progressing crisis of the prestige of the "resurrected" state. While the motif of compassion and magnanimity was conspicuous from the very onset, the emphasis placed upon it changed with time. The mollification of the royal likeness from that of a military victor displaying mercy to a philanthropist was characteristically accompanied by a decisive reinforcement of the autocratic position of the government in the lands on the banks of the Vistula.

Translated by Aleksandra Rodzińska-Chojnowska

\section{Bibliografia}

Alings, Reinhard. Monument und Nation. Das Bild vom Nationalstaat im Medium Denkmal - zum Verhältnis von Nation und Staat im deutschen Kaiserreich 1871-1918. Berlin: Walter de Gruyter, 1996.

Altendorf, Bettina B. Die russischen Sänger des Königs und die Kolonie Alexandrowka in Potsdam. Berlin: Bässler, 2004.

Bandtkie, Jerzy Samuel. Krótkie wyobrażenie dziejów Królestwa Polskiego. T. 2. Wrocław: Wilhelm Bogumił Korn, 1810.

Barańska, Anna. „Praktyka polska Aleksandra I”. W Wolnomularstwo Narodowe. Walerian Łukasiński, red. Wiktoria Śliwowska, 37-72. Warszawa: Instytut Historii PAN, 2014.

Bartoszewicz, Kazimierz. Utworzenie Królestwa Kongresowego. Kraków: Centralne Biuro Wydawnictw N.K.N., 1916.

Burdziej, Bogdan. „«Tytuł Północy» - Aleksander I w polskiej literaturze okolicznościowej 1801-1826". Litteraria Copernicana 7, nr 1 (2011): 18-49.

Carrier, Peter. Holocaust Monuments and National Memory Cultures in France and Germany since 1989. New York: Berghahn Books, 2005.

Czyżewski, Krzysztof J., Marek Walczak. „Kult świętego Stanisława w wieku XVIII w perspektywie sztuki”. W Praeminado incitat. Order świętego Stanisława 1765-1831, red. Michał Zawadzki, Dariusz Nowacki, 14-42. Warszawa: Zamek Królewski w Warszawie, 2015. 
Dąbrowicz, Elżbieta. Galeria ojców. Autorytet publiczny w literaturze polskiej lat 18001861. Białystok: Wydawnictwo Trans Humana, 2009.

Deszczyńska, Martyna. „Historia sacra” i dzieje narodowe. Refleksja historyczna z lat 1795-1830 nad rola religii i Kościoła w przeszłości Polski. Warszawa: Wydawnictwo Naukowe Semper, 2003.

Galant, Wojciech. Skarbiec świętych pańskich. Żywoty świętych na wszystkie dni w roku. Monachium: Karol Aug. Seyfried i Sp., 1926.

Getka-Kenig, Mikołaj. Ojcowie „wskrzeszonej” ojczyzny. Senat w rzeczywistości społeczno-politycznej Księstwa Warszawskiego. Warszawa: Neriton, 2013.

Gołębiowski, Łukasz. Opisanie historyczno-statystyczne miasta Warszawy. Warszawa: N. Glücksberg, 1827.

Grabski, Andrzej Feliks. Myśl historyczna polskiego oświecenia. Warszawa: Państwowe Wydawnictwo Naukowe, 1976.

Grześkowiak-Krwawicz, Anna. Regina libertas. Wolność w polskiej myśli politycznej XVIII wieku. Gdańsk: słowo/obraz terytoria, 2006.

Hazareesingh, Sudhir. The Saint-Napoleon. Celebration of Sovereignty in Nineteenth-Century France. Cambridge, Mass.: Harvard University Press, 2004.

Hoock, Holger. Empires of the Imagination. Politics, War, and the Arts in the British World, 1750-1850. London: Profile Books, 2010.

Jaroszewski, Tadeusz Stefan. Chrystian Piotr Aigner. Architekt warszawskiego klasycyzmu. Warszawa: Państwowe Wydawnictwo Naukowe, 1970.

Jaroszewski, Tadeusz Stefan. Kościół św. Aleksandra. Warszawa: Państwowe Wydawnictwo Naukowe, 1973.

Karpińska, Małgorzata. „Nie ma Mikołaja!”. Starania o ksztatt sejmu w powstaniu listopadowym 1830-1831. Warszawa: Neriton, 2007.

Kwiatkowski, Marek. Belweder. Warszawa: Państwowe Wydawnictwo Naukowe, 1976.

Kwiatkowski, Marek. „Nieznane widoki i plany warszawskich odwachów i rogatek celnych". Biuletyn Historii Sztuki 21, nr 1 (1959): 84-91.

Kwiatkowski, Marek. Stanisław August - król-architekt. Wrocław: Zakład Narodowy im. Ossolińskich, 1983.

Leskiewiczowa, Janina, Franciszka Ramotowska, red. Obraz Królestwa Polskiego w okresie konstytucyjnym. T. 1, Raporty Rady Stanu Królestwa Polskiego z działalności rzadu w latach 1816-1828. Warszawa: Państwowe Wydawnictwo Naukowe, 1984.

Łepkowski, Tadeusz. „Naród bez państwa”. W Polska. Losy państwa i narodu, red. Henryk Samsonowicz et al., 225-410. Warszawa: Iskry, 1992.

Łukasiński, Walerian. Pamiętnik. Warszawa: Państwowe Wydawnictwo Naukowe, 1960.

Markiewiczowa, Hanna. Działalność opiekuńczo-wychowawcza Warszawskiego Towarzystwa Dobroczynności. Warszawa: Akademia Pedagogiki Specjalnej, 2010.

Marschall, Sabine. Landscape of Memory. Commemorative Monuments, Memorials and Public Statuary in Post-apartheid South Africa. Leiden: Brill, 2010.

Michalski, Sergiusz. Public Monuments. Art in Political Bondage 1870-1997. London: Reaktion Books Ltd., 1998.

Mycielski, Maciej. Rząd Królestwa Polskiego wobec sejmików i zgromadzeń gminnych 1815-1830. Warszawa: Wydawnictwo Uniwersytetu Warszawskiego, 2010.

[Ostrowski, Antoni]. Żywot Tomasza Ostrowskiego. T. 2. Paryż: Księgarnia Polska, 1840. 
Pasquali, Susanna. „From the Pantheon of Artists to the Pantheon of Illustrious Men: Raphael's Tomb and its Legacy". W Pantheons: Transformations of a Monumental Idea, red. Richard Wrigley, Matthew Craske, 35-56. Aldershot: Routledge, 2004.

Paszkiewicz, Piotr. „Carskie pomniki i architektura okazjonalna w Warszawie (18151915). Treści i funkcje ideowe”. Biuletyn Historii Sztuki 52, nr 3/4 (1990): 287-317.

Paszkiewicz, Piotr. Pod berłem Romanowów. Sztuka rosyjska w Warszawie 1815-1815. Warszawa: Instytut Sztuki Polskiej Akademii Nauk, 1991.

Petit, Vincent. „Religion du souverain, souverain de la religion: l'invention de saint Napoléon". Revue Historique 314, nr 3 (2012): 643-658.

Pickering, Paul A., Alex Tyrell, red. Contested Sites, Commemoration, Memorial and Popular Politics in Nineteeth-Century Britain. Aldershot: Ashgate, 2004.

Pohlsander, Hans A. National Monuments and Nationalism in 19th Century Germany. Bern: Peter Lang, 2008.

Polaczek, Janusz. Sztuka i polityka w Księstwie Warszawskim. Rzeszów: Wydawnictwo Uniwersytetu Rzeszowskiego, 2005.

Prutsch, Markus J. „«Monarchical Constitutionalism» in Post-Napoleonic Europe. Concept and Practice". W Constitutionalism, Legitimacy, and Power. Nineteenth-Century Experiences, red. Kelly L. Grotke, Markus J. Prutsch, 69-83. Oxford: Oxford University Press, 2014.

Przelaskowski, Ryszard. Sejm warszawski roku 1825. Warszawa: Towarzystwo Naukowe Warszawskie, 1929.

Rastawiecki, Edward. Słownik malarzów polskich, tudzież obcych w Polsce osiadłych lub czasowo w niej przebywajacych. T. 2. Warszawa: Drukarnia S. Orgelbranda, 1851.

Rausch, Helke. Kultfigur und Nation. Öffentliche Denkmäler in Paris, Berlin und London 1848-1914. München: R. Oldenbourg Verlag, 2006.

Savage, Kirk. Standing Soldiers, Kneeling Slaves. Race, War, and Monument in Nineteenth-Century America. Princeton: Princeton University Press, 1997.

[Schmidtner, Leonard]. Zbiór celniejszych gmachów miasta stołecznego Warszawy. T. 2-3. Warszawa: Litografia D[aniela] Knusmanna, 1823-1824.

Schrauwers, Albert. „The «Benevolent» Colonies of Johannes van den Bosch: Continuities in the Administration of Poverty in the Netherlands and Indonesia". Comparative Studies in Society and History 43, nr 2 (2001): 298-328.

Sierakowski, Sebastian. Architektura obejmująca wszelki gatunek murowania $i$ budowania. T. 1. Kraków: Drukarnia Akademicka, 1812.

Skarbek, Fryderyk. O ubóstwie i ubogich. Warszawa: Drukarnia Gałęzowskiego, 1827.

Smolka, Stanisław, red. Korespondencja Lubeckiego z ministrami i sekretarzami stanu Ignacym Sobolewskim i Stefanem Grabowskim. T. 3. Kraków: Akademia Umiejętności, 1909.

Trzebiński, Wojciech. „Aleksander I a działalność urbanistyczna rządu Królestwa Polskiego w latach 1815-1821". Kwartalnik Architektury i Urbanistyki 34, nr 1/2 (1989): 35-89.

Vick, Brian E. The Congress of Vienna. Power and Politics after Napoleon. Cambridge, Mass.: Harvard University Press, 2014.

Webster, Sally. The Nation's First Monument and the Origins of the American Memorial Tradition. Abingdon: Ashgate, 2015. 
Zajewski, Władysław. „Sołtyk Roman (1790-1843)”. W Polski Słownik Biograficzny, T. 40, 420-421. Warszawa: IH PAN, 2000-2001.

Żelazny, Czesław. „Geneza obelisku w Cytadeli. Na marginesie sprawy wzniesienia pomnika Traugutta”. Polska Zbrojna 3, nr 291 (1923): 3.

Biogram: dr Mikołaj Getka-Kenig - Instytut Historii Sztuki UJ, Kraków, historia kultury przełomu XVIII i XIX w., z naciskiem na polityczny wymiar sztuki i architektury, m.getka.kenig@gmail.com; mikolaj.getka-kenig@uj.edu.pl. 